\title{
Comparison of trace element chemistry in human bones interred in two private chapels attached to Franciscan friaries in Italy and Denmark: an investigation of social stratification in two medieval and post-medieval societies
}

Kaare Lund Rasmussen ${ }^{1 *}\left(\mathbb{0}\right.$, Thomas Delbey ${ }^{1}$, Paolo d'Imporzano ${ }^{2}$, Lilian Skytte ${ }^{1}$, Simone Schiavone 3 , Marielva Torino ${ }^{4}$, Peter Tarp ${ }^{5}$ and Per Orla Thomsen ${ }^{6}$

\begin{abstract}
Individuals buried in two 17th-18th Century private chapels, each attached to a Franciscan Friary —one in Italy the other in Denmark — have been studied and sampled for trace element analysis. This selection of individuals allows a comparison of the trace element inventory of members of noble families against friars and townspeople, as well as a comparison between two very similar situations in Denmark and Italy. The relevance of this study is to see if and how differences in social status, and therefore likely differences in dietary habits, are reflected in the trace element chemistry of the bones. Samples of cortical and trabecular tissues have been procured from a long bone, preferentially the femur. The samples have been thoroughly decontaminated. 87 samples from 69 individuals have been analysed for $\mathrm{Ca}, \mathrm{Mn}, \mathrm{Fe}, \mathrm{Cu}, \mathrm{Sr}, \mathrm{Ba}$, and Pb by ICP-MS and Hg by CV-AAS. Sex and age at death have been established by anthropological analysis for all members of the two noble families. We find systematic differences between the noble family members and the friars (or townspeople) in both Italy and Denmark. The noble families are in both cases low in Sr and Ba compared to the friars and townspeople, which is interpreted as a dietary signal resulting from higher meat consumption than in the comparative groups. Lead concentrations are found to be higher in the noble family members than in the comparative groups, and the $\mathrm{Pb}$ concentration seems to increase with age in the Italian noble family, where both young and middle-aged individuals were investigated. Mercury concentrations are higher in some of the Italian noble family members compared to friars and townspeople; whereas in Denmark it seems that $\mathrm{Hg}$ was equally available to the noble family members and the friars alike. This is the first comprehensive and comparative study of post-medieval noble families in Denmark and Italy. The results show that there are distinct similarities in the trace element distribution patterns in the noble family members irrespective of country, which is tentatively suggested to be due to their higher social status.
\end{abstract}

Keywords: Noble families, Strontium, Barium, Copper, Lead, Mercury, Trace element chemistry, Hardenberg, lannelli, Franciscan friaries, Meat consumption

\footnotetext{
*Correspondence: klr@sdu.dk

${ }^{1}$ Cultural Heritage and Archaeometric Research Team (CHART),

Department of Physics, Chemistry and Pharmacy, University of Southern

Denmark, Campusvej 55, 5230 Odense M, Denmark

Full list of author information is available at the end of the article
}

Springer Open

(c) The Author(s) 2020. This article is licensed under a Creative Commons Attribution 4.0 International License, which permits use, sharing, adaptation, distribution and reproduction in any medium or format, as long as you give appropriate credit to the original author(s) and the source, provide a link to the Creative Commons licence, and indicate if changes were made. The images or other third party material in this article are included in the article's Creative Commons licence, unless indicated otherwise in a credit line to the material. If material is not included in the article's Creative Commons licence and your intended use is not permitted by statutory regulation or exceeds the permitted use, you will need to obtain permission directly from the copyright holder. To view a copy of this licence, visit http://creativeco mmons.org/licenses/by/4.0/. The Creative Commons Public Domain Dedication waiver (http://creativecommons.org/publicdomain/ zero/1.0/) applies to the data made available in this article, unless otherwise stated in a credit line to the data. 


\section{Introduction}

The present investigation presents a comparison of individuals with higher social rank to those of lower social rank, giving for the first time a description of the possible dietary and environmental differences of the socially stratified medieval and post-medieval societies in Denmark and Italy, as well as a comparative study between Denmark and Italy. The strength of the present study lies in the selection of individuals, which contains a constellation with a suite of individuals from two noble families buried in two private chapels-one in Montella Italy [1, 2] the other in Svendborg Denmark [3, 4]-where the trace element concentrations $\mathrm{Sr}, \mathrm{Ba}, \mathrm{Cu}$, and $\mathrm{Pb}$ are compared with data from individuals of presumably lower social status buried less than tens of meters away, in the cloister walks of the two friaries.

\section{Strontium and barium}

Strontium and $\mathrm{Ba}$ are two non-essential elements mainly ingested through food and water. They are not homeostatically regulated [5]. Both elements are absorbed from the gastrointestinal track, enters the bloodstream, and are excreted in various proportions. Most of the absorbed $\mathrm{Sr}$ and $\mathrm{Ba}$ are eventually deposited in bones and teeth.

The use of $\mathrm{Sr}$ and $\mathrm{Ba}$ as dietary indicators has a long history in archaeometry, which started out in a very positive mode [6-11]. The theoretical background supporting this use is related to the decrease of the $\mathrm{Sr} / \mathrm{Ca}$ and $\mathrm{Ba} / \mathrm{Ca}$ ratios through each step of the trophic chain by the biopurification of $\mathrm{Ca}[12,13]$. The decrease was found to be constant through the trophic chain and it was therefore able to explain the correlation between this pair of ratios along the "Ca biopurification line" [14]. Later, the concept of using $\mathrm{Sr}$ and Ba concentrations for dietary reconstruction studies was dismantled [15-17], and the focus was shifted almost entirely to stable isotope ratios using $\mathrm{C}$ and $\mathrm{N}$ isotopes for reconstructing diet, and Sr-isotopes for provenancing human bones (e.g. [18] and references therein). The reasons for discrediting the use of elemental concentrations of $\mathrm{Sr}$ and $\mathrm{Ba}$ in the 1990s were two-fold. The first was the realization that there did not exist a linear translation from the Sr-concentration in foodstuff to the Sr-concentration in human bones [19]. The second was the realization that diagenesis could affect the $\mathrm{Sr}$ and Ba concentrations [16, 20-26]. Lately, it has been argued that even though $\mathrm{Sr}$ is classified as a non-essential element, its distribution in the human body could be tied to elements regulated by metabolic processes such as $\mathrm{Zn}$. Thus, Sr measurements could somehow be misinterpreted because of "homeostatic overprinting" [27].

However, in recent years studies of the elemental concentrations of $\mathrm{Sr}$ and $\mathrm{Ba}$ have been taken up again
[28-32]. Despite of the concerns for diagenesis, the use of an analytical strategy including a thoughtful sampling plan, intra-site comparisons and meticulous observations of the distribution of the elements can sometimes overcome the diagenetic issue, if it is present at the site investigated. It has become clear that not only stable isotope ratios of e.g. Sr, C, N, and S, but also elemental concentrations of $\mathrm{Sr}$ and $\mathrm{Ba}$ can provide information about the diet and therefore possibly the provenance of people in the past.

Even in cases where there are no diagenetic alterations, the 1995 conclusion of Burton and Wright [19] still stands, in the sense that the Sr-concentration in human bones cannot be used as a 1:1 measure of the diet, e.g. mapping directly the consumption of animal meat. A large consumption of meat will indeed result in a lower $\mathrm{Sr}$-concentration in the bones, but the picture can be much more complicated than a linear relationship. One factor affecting the $\mathrm{Sr}$ and $\mathrm{Ba}$ concentrations is the biopurification against $\mathrm{Ca}$, i.e. that any bone or shell bearing organism including the human body will suppress the $\mathrm{Sr}$ and $\mathrm{Ba}$ concentrations over the $\mathrm{Ca}$ concentration. An addition of for instance shellfish to the diet will lead to increased $\mathrm{Sr}$ and $\mathrm{Ba}$ concentrations, whereas a diet rich in freshwater fish will lower the $\mathrm{Sr}$ and Ba concentrations (see Fig. 8 in [32]).

It remains standing today that $\mathrm{Sr}$ and $\mathrm{Ba}$ can be viewed as provenance indicators due to differences in bioavailability as a function of geographical area or equally possible: changes in diet of the individual. Some geographical areas, although certainly not globally, have been mapped for the concentrations of present-day bioavailability of $\mathrm{Sr}$ and Ba (e.g. for modern day Denmark, see Fig. 3e in [33]). How the present-day bioavailability map translate to medieval bioavailability is more uncertain. Bioavailable $\mathrm{Sr}$ and $\mathrm{Ba}$ enter the human body through drinking water and derivatives thereof, such as beer and cooked food, and through locally grown vegetables, when these are watered with the local water and can in this way be perceived as provenance indicators. The alternative possibility-that differences in concentrations of $\mathrm{Sr}$ and $\mathrm{Ba}$ are reflecting changes in the diet of an individual-is also a viable interpretation and indistinguishable from the provenance interpretation [32].

\section{Mercury}

Mercury is a non-essential and toxic heavy metal. It can be found in the environment in the elemental form, as well as in inorganic and organic compounds, the latter mainly originating from biomethylating processes. All three forms can enter in the human body through different pathways and have different solubilities, reactivities, and toxicity properties [34]. Elemental and inorganic $\mathrm{Hg}$ 
primarily accumulate in the kidneys before it is eventually distributed in the body via the bloodstream and from here enters several organs such as the central nervous system and the brain. The organic form enters the liver, the blood cells, the bone marrow, the central nervous system, the brain, and the respiratory mucosa. Organic mercury may be metabolized in the liver before being excreted through bile and reabsorbed in the gastrointestinal pathway [35]. Regardless of the route of the $\mathrm{Hg}$ exposure, intoxication can lead to severe health issues such as systemic, immunologic, neurologic, carcinogenic, or reproductive effects [36].

In medieval and renaissance times mercury was mined as HgS-ore (cinnabar) from at least one mine-the mine situated at Almaden Spain [37]. Cinnabar was a rare commodity which were transported vast distances by trade routes. Mercury had an extremely low environmental occurrence in most medieval societies in both Denmark and Italy [2, 32]. Even so, Hg has been found in high concentrations in medieval and post-medieval human individuals in several studies [2, 32, 38-56]. Some individuals were only exposed to the environmental $\mathrm{Hg}$ background, which has been estimated to correspond to $80 \mathrm{ng} \mathrm{g}^{-1}$ in cortical and $300 \mathrm{ng} \mathrm{g}^{-1}$ in trabecular bone tissue in Danish and German medieval and post-medieval skeletons [46]. For the individuals exhibiting $\mathrm{Hg}$ concentrations higher than the background level, there can be one of only a few possible causes: (1) intake, preparation, or administration of $\mathrm{Hg}$-containing medicine; (2) reading or writing texts written with ink containing the red colour pigment cinnabar ( $\mathrm{HgS}$ ) including working in the scriptorium with the preparation of the red ink; (3) partaking in a gilding process that uses amalgamation with $\mathrm{Au}$ and $\mathrm{Hg}$; (4) working in $\mathrm{Hg}$ mines. The two latter processes must be relatively rare compared to the two former exposure ways, at least in medieval and post-medieval Denmark and Campania. It has been shown that $\mathrm{Hg}$ was used in medieval and post-medieval times as a cure for both leprosy and treponema infections [43, 46, 57]. Therefore, if the $\mathrm{Hg}$ concentration in an individual is found to be at or below the environmental background level, this excludes that this individual received medication containing $\mathrm{Hg}$ or partook in any of the above-mentioned processes in the last appreciable time before death. In one instance, the case of San Francesco Caracciolo now resting in the Cathedral in Naples, it has been shown that a medication with $\mathrm{Hg}$ could be detected in cortical tissue 22 years after the medication took place [57]. It is highly unlikely that $\mathrm{Hg}$ in measurable amounts could originate from the diet in either location of the present study.

Diagenetic deposition of $\mathrm{Hg}$ in human bones originating from the surrounding soil has not been observed in the many studies focusing on $\mathrm{Hg}$ measurements in human bones (see [51] and references therein). A likely explanation is that the environmental exposure is generally very low, and that sulphur containing compounds are abundantly present during the decay process of the body, which reacts with $\mathrm{Hg}$ to form the very stable and insoluble $\mathrm{HgS}$ [46].

\section{Lead}

Lead is a toxic heavy metal and a non-essential trace element in the human body. Lead absorption mainly occurs through ingestion and inhalation before entering the blood stream. The $\mathrm{Pb}$ subsequently enters the soft tissues and the bones, followed by an excretion through the kidneys and the urine. In the human body $90-95 \%$ of the $\mathrm{Pb}$ burden is located in the bones. The incorporation usually occurs by divalent $\mathrm{Pb}^{2+}$ substituting for $\mathrm{Ca}^{2+}$ in the hydroxyapatite during the bone modelling or remodelling processes [58]. In vitro studies have shown that $\mathrm{Pb}$ can be fixed in hydroxyapatite via several pathways such as ionic exchange, surface complexation, and dissolution-precipitation $[59,60]$. Acute $\mathrm{Pb}$ exposure can have severe consequences including chronic diseases in nervous, skeletal, renal, and endocrine systems [61].

The use of $\mathrm{Pb}$ as a biomarker in archaeology has been rising in the last decades since the relationship between the $\mathrm{Pb}$ concentration in bones and $\mathrm{Pb}$ concentration in blood have been established [62, 63]. It has been successfully used on human and animal bones as a marker for detecting environmental pollution linked to urbanization and metal industry in past societies [46, 64-68], but also for drawing inferences about social status in populations where the use of $\mathrm{Pb}$ can be seen as a discriminating social factor [32, 39, 46, 69-71].

Recent archaeological studies show some concern about the possibility of diagenetic alteration of the $\mathrm{Pb}$ signal in bones coming from the surrounding sediment $[23,72]$ or from anthropogenic soil pollution [73, 74]. Since $\mathrm{Pb}$ can substitute for $\mathrm{Ca}$ in the hydroxyapatite, it has been suggested that diagenetic $\mathrm{Pb}$ could enter the bones according to a similar pathway as what has been seen in in vitro experiments, i.e. that cations in solution enter the pores of the bone and then recombine with hydroxyapatite during a recrystallisation process or via ionic exchange [13, 72]. Lead salts are usually quite insoluble under alkaline conditions, while their solubility can increase drastically in highly acidic environment [75]. However, acidic conditions are never present in cemetery soil environments with well-preserved bones, like the bones in the present study. 


\section{Copper}

Copper is an essential trace element involved in several metabolic processes in the human body, including the functioning of the immune system [76-81]. Copper absorption originating from the diet mainly occurs through the small intestine, while the liver plays a role in the regulation of the $\mathrm{Cu}$ load through excretion, which happens via the bile entering the gastrointestinal tract in a form that prevents reabsorption. The absorption and excretion of $\mathrm{Cu}$ normally vary according to dietary intake to maintain a desired level in the body [76, 77, 80, 82]. From the perspective of the skeleton, $\mathrm{Cu}$ deficiency has been linked to osteoporosis, decreased bone strength, and femoral head necrosis [83, 84].

Copper concentrations in archaeological bones have been used as a palaeodietary indicator to identify a diet rich in meat [85-87], but the relationship between $\mathrm{Cu}$ uptake and dietary composition is still unclear [88, 89]. The impact of $\mathrm{Cu}$-exposure on medieval and post-medieval populations through the use of kitchen utensils and environmental factors have been investigated and it has been argued that the $\mathrm{Cu}$ concentrations in bones indicate either a higher social class or a higher degree of urbanisation (see [90] and references therein).

The possibility of diagenetic effects of $\mathrm{Cu}$ in bones have been emphasised by several of the before mentioned studies. Evidence of post-mortem alteration in cortical bone have been found in archaeological contexts with a heavy anthropic $\mathrm{Cu}$-pollution linked to the nature of the site, such as a medieval metal-workshop in France [79], but also in Neolithic animals bones [91]. The present study does not deal with either heavily anthropogenically polluted areas, or very old bones, so the bones in the present study are not pre-disposed to diagenetic changes in the $\mathrm{Cu}$ concentrations.

\section{Excavation sites}

\section{The Franciscan friary of Svendborg}

The medieval town of Svendborg was situated on the south coast of the island of Funen in Denmark (Fig. 1a). The Franciscan Friary in Svendborg was founded in AD 1236 at a site which in its day was near the shoreline but still within the medieval city limits. The friary was modified and enlarged several times, most substantially in AD 1361. In the renaissance period, by the end of 16th Century, the Hardenberg Chapel was erected north of the church choir with an entrance into the church room. The chapel was a small almost square structure of $5.6 \times 6.0 \mathrm{~m}$ built of red bricks on a granite plinth. Most of the friaryexcluding the Hardenberg Chapel and the northern wall of the friary church-was demolished in 1828 (Fig. 1b, c). The Hardenberg Chapel and the remainder of the north wall of the church was finally demolished in 1876 when the railway came to Svendborg. The friary and the chapel were excavated by Svendborg og Omgens Museum in 1975-1976, where a burial crypt with the dimensions $4.0 \times 2.6 \mathrm{~m}$ was discovered underneath the chapel floor (Fig. 1d). The walls of the crypt were made of redbrick (one stone in thickness) and built up against the sides of the pit dug for the crypt. The floor of the crypt was paved with unglazed tiles. Both the chapel above and the crypt were seemingly used for burials. The name of the chapel suggests that it was erected by Helvig Hardenberg (15401599, widow of Erik Rosenkrantz), who owned part of the friary in 1586 [3]. In the cloister walk, less than ten meters from the chapel, were unearthed eleven individuals, all males; and some 50 meters further to the south of the friary was unearthed a layman cemetery [3].

\section{The Franciscan friary near Montella}

The $S$ Francesco a Folloni friary was erected c.1 km northeast of the medieval town of Montella, which is situated on the slope of the Picentini mountain range in the Avellino province of the Campania region in Southern Italy (Fig. 2a-c). The friary was founded by St. Francis of Assisi himself during a trip to the sanctuary of St. Michele at Gargano in the winter AD 1221-2. The Iannelli Chapel was added in the $1620^{\prime}$ s, when Giovanni Bernardino Iannelli granted a large sum of money to the friars for the realization of a chapel [1] and of an altar to contain the relic of the sack of St. Francis [92] and with a guarantee of obtaining there the final resting place for himself and his loved ones.

An earthquake demolished most of the friary in 1732 but left the Iannelli crypt intact. When the friary was rebuilt by the Franciscan Order between 1746 and 1750 the new church was rotated $90^{\circ}$ around the position of the original altar, still leaving the Iannelli crypt untouched $[1,2]$. The cloister walk and the Iannelli crypt were excavated during two extensive excavations of the friary in 2007-2008 and again in 2010 under the supervision of S. Schiavone [1]; the study of the skeletons was conducted under the supervision of M. Torino $[2,93]$. Due to the find of both males and females in the cloister walk, it is likely that the cloister walk was used as a burial place for both friars and townspeople alike. The individuals selected in the Iannelli crypt were mostly middle-aged males, although one child and one adolescent were also included. The oldest individuals were ca. 65 years of age. Four individuals showed signs of syphilis and five of tuberculosis. Two photos from the excavation of the crypt under the Iannelli Chapel are shown in Fig. 2d, e. In connection with a male individual (grave no. 16) there was found a small votive medal bearing the effigy of St. Ignazio de Loyola and St. Francesco Saverio [1]. Which-for this 
a

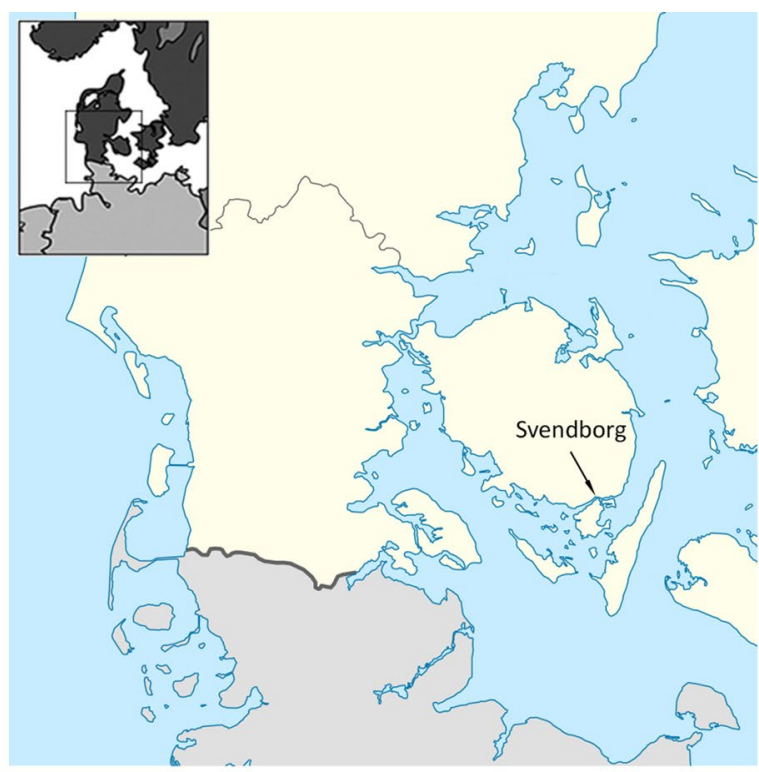

b

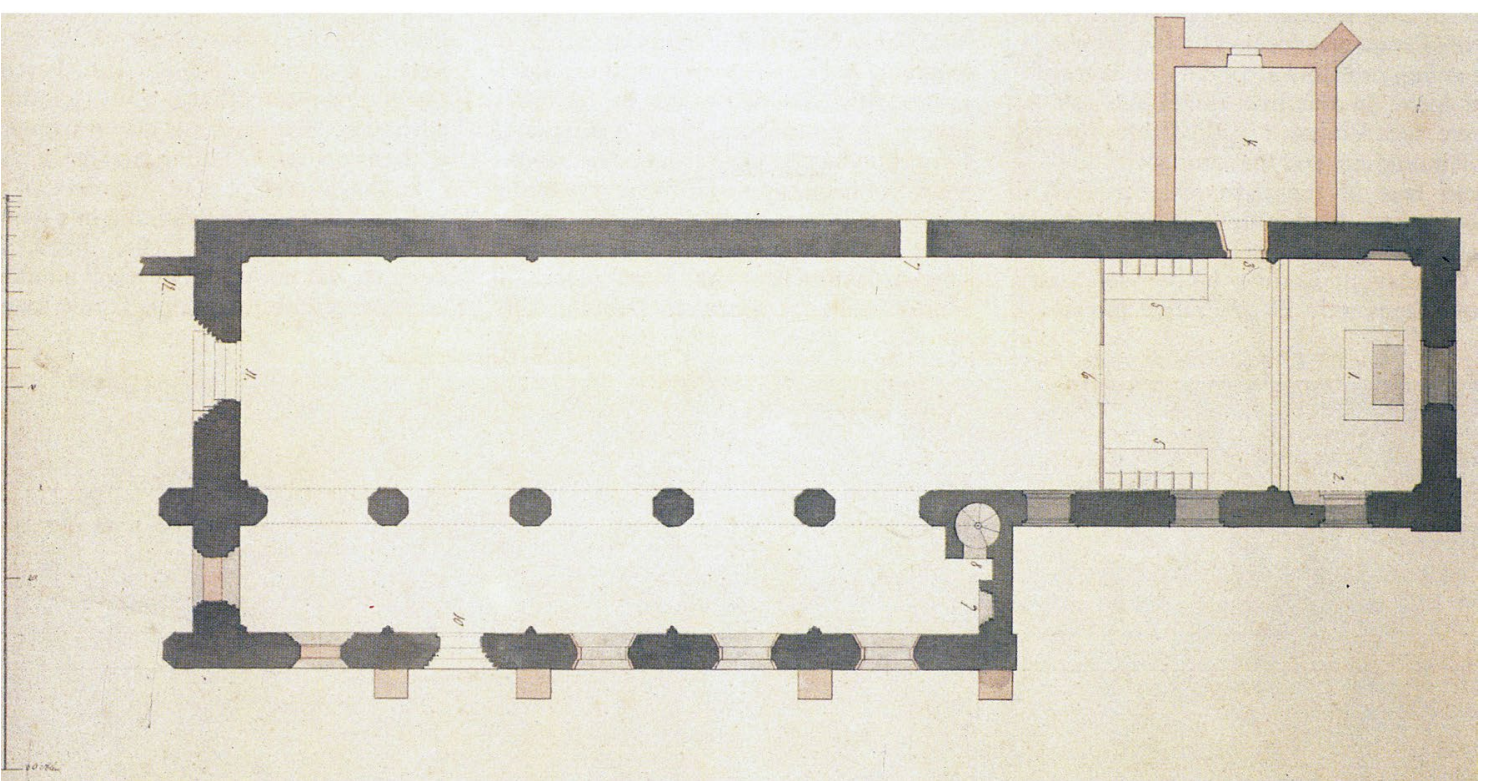

Fig. 1 a Map showing the position of Svendborg in Denmark. Insert: position of Denmark; b plan of the Franciscan Friary Church of Svendborg prior to demolition of the church in 1828. North is up. Hand drawing by C.F. Thorin. The position of the Hardenberg Chapel is marked by "4" and can be seen in red in the upper right of the drawing; c watercolour depicting the Hardenberg Chapel seen from the north after the demolition of the church in 1828. Painted by S. Rænkel in 1885 (Svendborg Museum no. 5.422); $\mathbf{d}$ archaeological area map showing details of the crypt floor of the Hardenberg Chapel made during the excavation

individual-points to a burial after 1623, the year of the canonization of the two Jesuits.

\section{Sampling strategy}

Two samples were taken from each individual when possible, a sample of cortical tissue and one of trabecular tissue. When available, the femur was sampled. 17 individuals interred in the Iannelli crypt were sampled, and as comparative material 34 individuals from the cloister walk of the friary have been analysed. The individuals interred in the cloister walk undoubtedly include several friars, but equally likely also paying citizens from the nearby Montella village, particularly so, since both children and women were found in the 


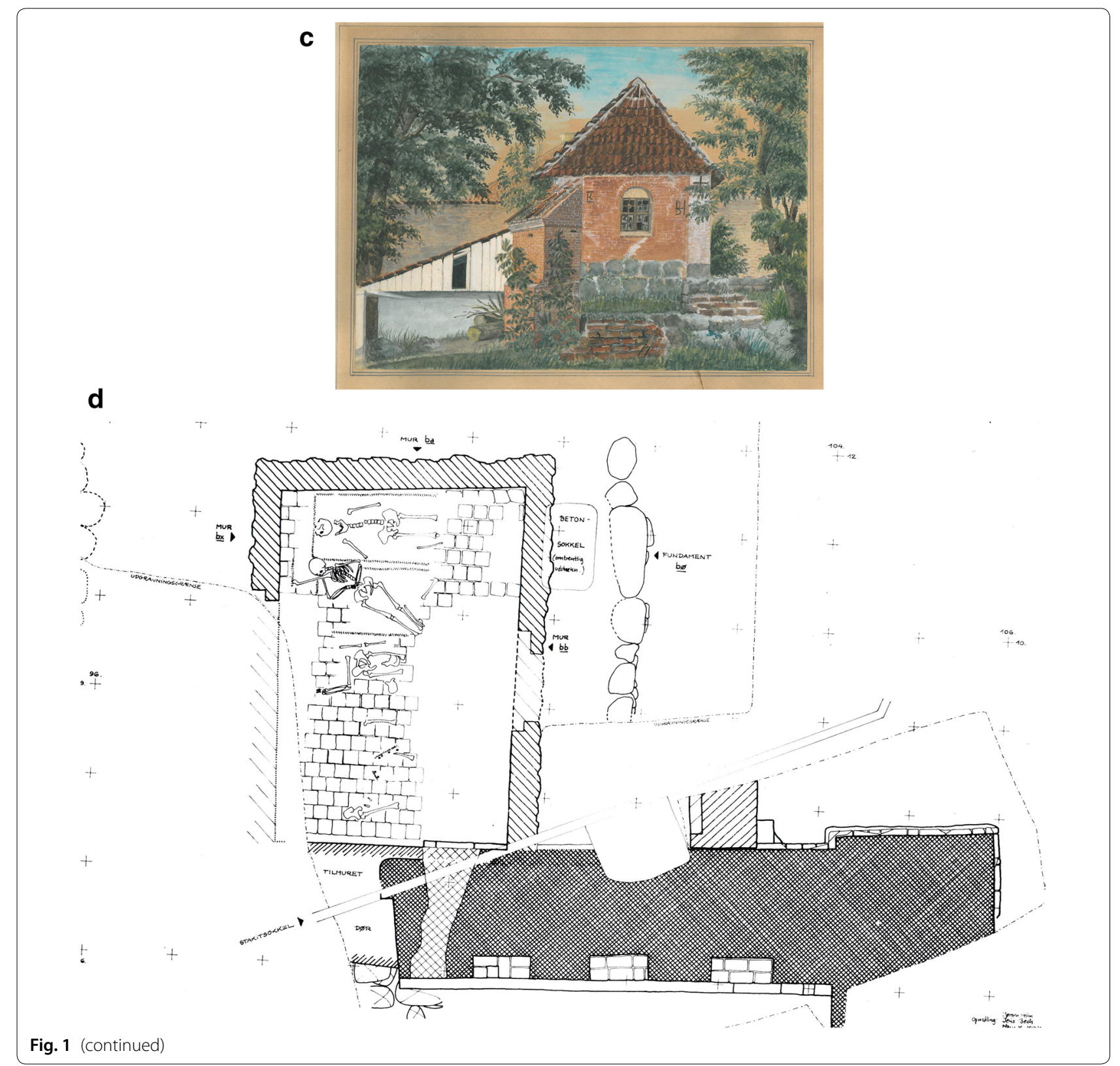

cloister walk [1, 2]. The individuals from the cloister walk are most likely older than ca. AD 1500 (see radiocarbon dates in [2]). The individuals from the Iannelli crypt are most likely from 1614 - the time of the erection of the chapel-to 1643. In 1643 Bartolomeo Orazio (1601-1650) moved his family to Civitella del Tronto in Abruzzo. It is considered unlikely, although possible, that burials were added after 1643 . The crypt was with certainty sealed when the Franciscan order re-build the friary between 1741 and 1750 following the devastating earthquake in 1732. The crypt was one of the few parts of the complex not demolished by the earthquake and not rebuild by the friars. There is therefore at least a 100 years, and possibly more, difference in age between the two groups. However, even despite this offset in date, the habitants lived in the same environment and in a rather static rural society which makes a comparison worthwhile. Information about sex and age at death have been ascertained for the Iannelli individuals and are listed in Table 1.

A similar sampling strategy has been adopted for the Hardenberg crypt. All seven individuals excavated from the Hardenberg crypt have been sampled. As a comparative material all 14 individuals excavated in the 


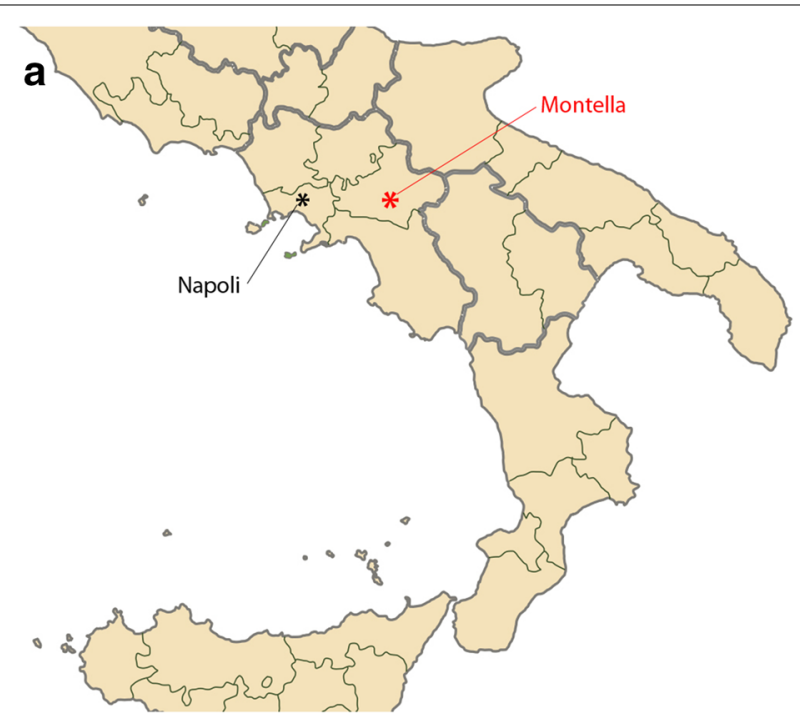

b

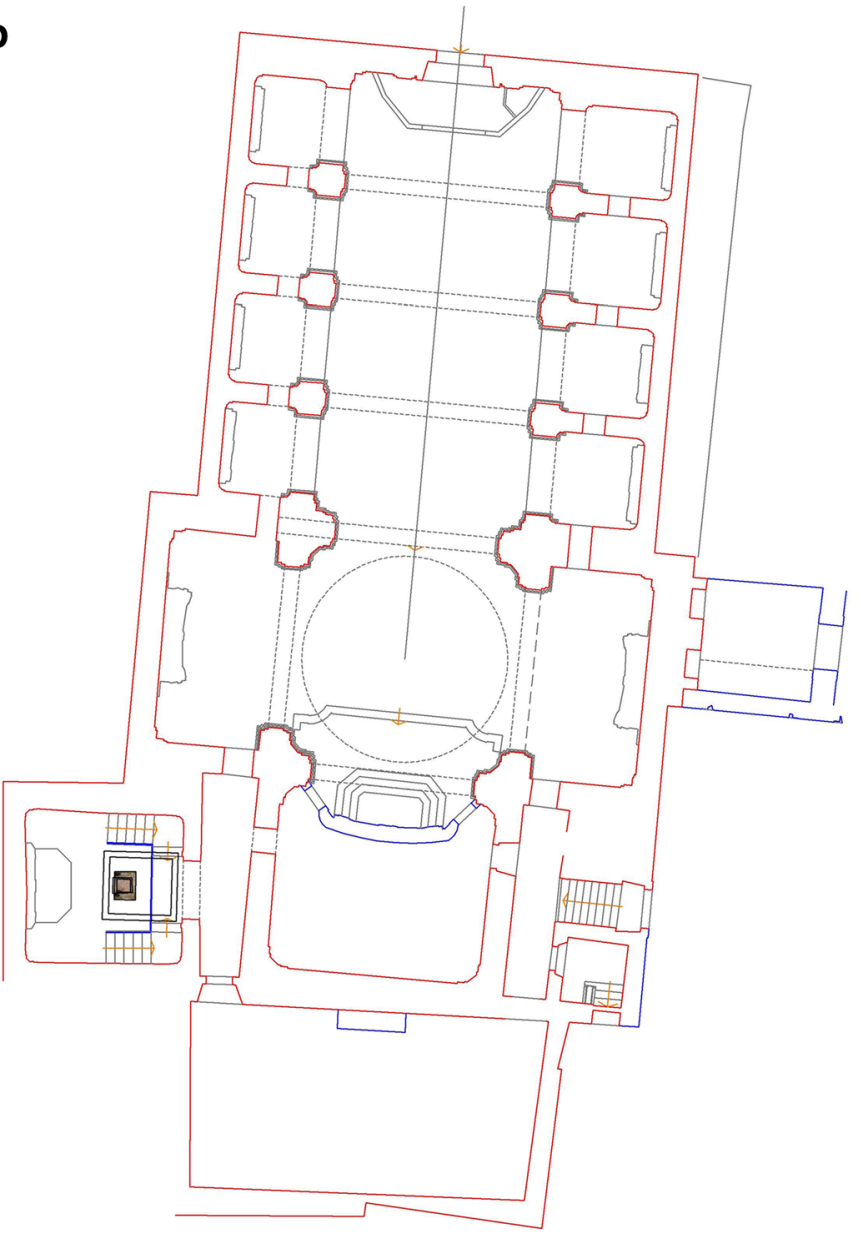

Fig. 2 a Map showing the position of Montella in Italy; b plan of the church of the Franciscan Friary at Folloni, near Montella AV, Southern Italy. The lannelli Chapel is seen at the lower left; c vertical section through the lannelli Chapel made during the excavation; $\mathbf{d}$ photo of the tombstone covering the access to the crypt prior to opening, placed according to the surroundings; e: Photo of the skeletons during the excavation, inserted into a drawing of the walls of the chapel and the access way (dashed lines) 


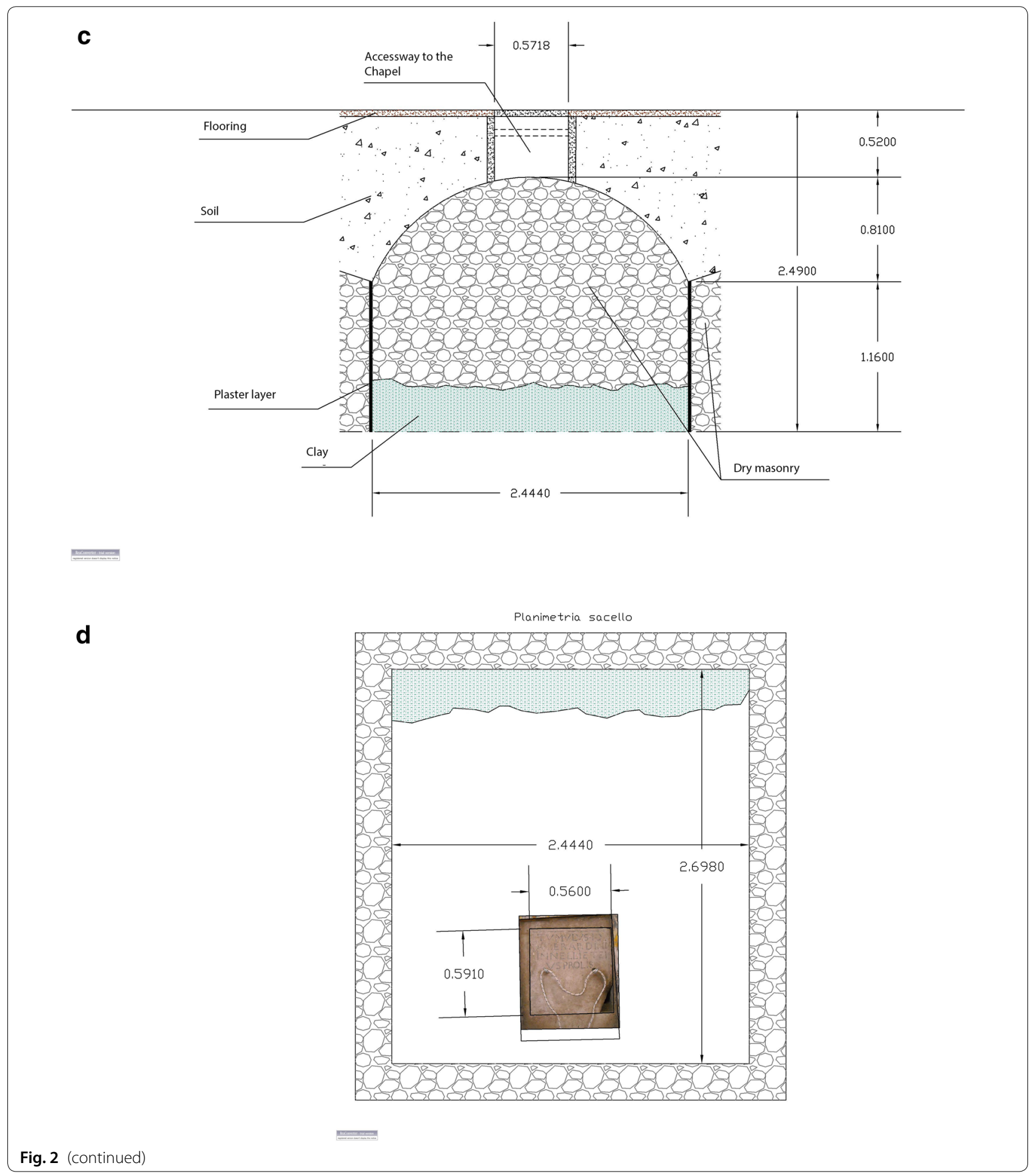

cloister walk of the Svendborg Franciscan Friary have been included in the study. There were no women or children among the individuals recovered from the cloister walk in Svendborg. However, contrary to [3], Kristensen now thinks it is likely that not all the individuals were friars [4]. Like in Montella there is a difference in the dating of the two groups. The individuals interred in the Hardenberg crypt lived in the 17th and 18th centuries, while the individuals from the cloister walk are likely from before the protestant reformation in 1536 . 


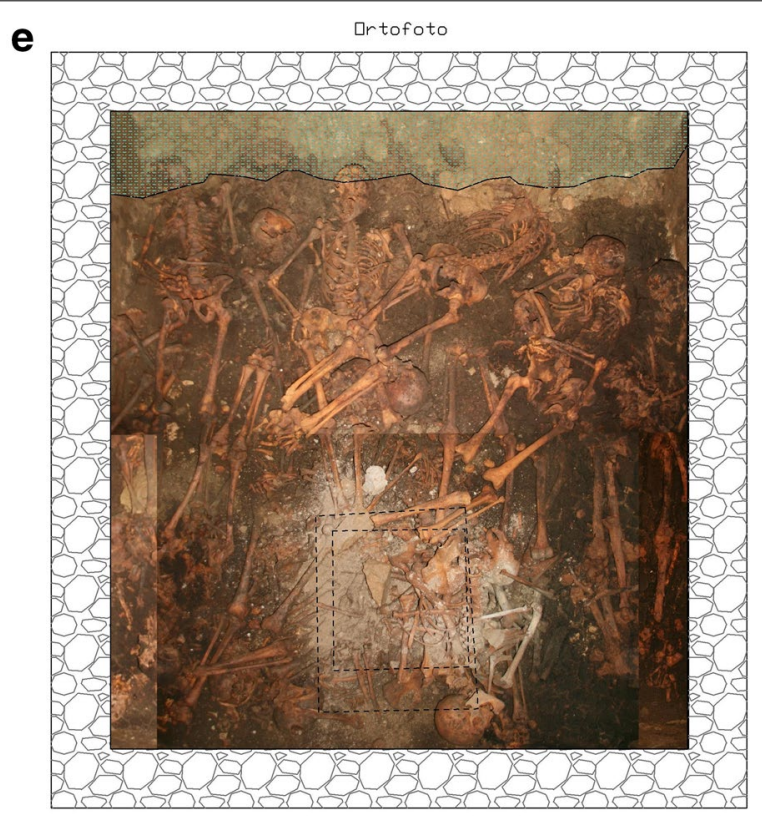

Fig. 2 (continued)

This means that there is a difference in age of no less than 75 years. Information about the individuals from the Hardenberg crypt are reported in Table 2.

\section{Experimental \\ Sampling}

The sampling was carried out using a Dremel Multi ProW drill (Robert Bosch) equipped with either an engraving drill or a saw blade. Prior to sampling the drill or saw blade was rinsed in MilliQ water (Merck Millipore) and then heated in an ethanol flame. The rinsing was carried out to avoid contamination from dust or leftover material from the last use. The heating was applied to rid the utensils of any remaining $\mathrm{Hg}$. The sampling took place on two sheets of clean aluminium foil, the lower to prevent contamination from the working table. The person taking the samples was equipped with hairnet, dust mask, lab coat, and disposable latex gloves. For each individual a sample of femoral cortical tissue was taken of the posterior part of the femur (enabling later exhibition of the bone) ca. $10 \mathrm{~cm}$ below the trochanter minor yet avoiding linea aspera. Before the cortical tissue samples were collected, the upper 1-2 $\mathrm{mm}$ of the bone was discarded, leaving a pristine sampling area of ca. $1 \times 2 \mathrm{~cm}$ devoid of soil particles. The top Al-foil were replaced before the actual sample was drilled from the decontaminated surface. The sampling yielded ca. $100 \mathrm{mg}$ of bone material.
In rare cases where a femur was not present or not well preserved, tibia or humeri were sampled instead.

The trabecular samples were collected from the inner part of the caput femoris. The samples were procured by drilling a hole with a diameter of ca. $5 \mathrm{~mm}$ in the caput, exposing the trabecular interior. The drill was rinsed, and gloves and Al-foil were replaced. Trabecular bone material was then removed from inside the hole, yielding ca. $100 \mathrm{mg}$ of partly crushed trabecular lamellae. The sample was collected and transferred to a pre-cleaned glass vial. In some cases, the trabecular tissue was pristine, in other cases soil particles had found their way into the caput femoris. If a sample-cortical or trabecular-appeared dark upon visual inspection, the sample was sorted under the microscope using clean tweezers and in this way getting rid of all particles of soil, dried organic material and other extraneous matter particles one at a time, leaving only clean bone; a tedious and time consuming, but necessary, practice. If a Ca concentration was found to be lower than $22.1 \mathrm{wt} \%$, a new sample was procured, as this could indicate the possible presence of soil particles.

\section{ICP-MS}

The major and trace elements $\mathrm{Ca}, \mathrm{Mn}, \mathrm{Fe}, \mathrm{Cu}, \mathrm{Sr}, \mathrm{Ba}$, and $\mathrm{Pb}$ were measured by ICP-MS (Inductively Coupled Plasma Mass Spectrometry) and Hg by CV-AAS (Cold Vapour Atomic Absorption Spectrometry). Each 
Table 1 List of individuals investigated from the lannelli Chapel

\begin{tabular}{|c|c|c|c|c|c|c|c|}
\hline Lab. no. & Sample & Age min & Age max & Sex & Diseases & Tissue & Type \\
\hline KLR-9429 & $\operatorname{lan} 1$ & 15 & 16 & Male & & Femur & $\mathrm{CO}$ \\
\hline KLR-9430 a & $\operatorname{lan} 2$ & 45 & 60 & Male & & Femur & $\mathrm{CO}$ \\
\hline KLR-9430 a & $\operatorname{lan} 2$ & 45 & 60 & Male & & Femur & TR \\
\hline KLR-9431 & $\operatorname{lan} 4$ & 19 & 22 & Male & & Femur & $\mathrm{CO}$ \\
\hline KLR-9432 & $\operatorname{lan} 5$ & 40 & 50 & Male & $\mathrm{TBC}$ & Femur & $\mathrm{CO}$ \\
\hline KLR-9432 & $\operatorname{lan} 5$ & 40 & 50 & Male & $\mathrm{TBC}$ & Femur & $\mathrm{TR}$ \\
\hline KLR-9433 & $\operatorname{lan} 7$ & 45 & 53 & Male & $\mathrm{TBC}$ & Femur & $\mathrm{CO}$ \\
\hline KLR-9433 & $\operatorname{lan} 7$ & 45 & 53 & Male & $\mathrm{TBC}$ & Femur & TR \\
\hline KLR-9434 & $\operatorname{lan} 8$ & 40 & 55 & Male & & Femur & $\mathrm{CO}$ \\
\hline KLR-9434 & $\operatorname{lan} 8$ & 40 & 55 & Male & & Femur & $\mathrm{TR}$ \\
\hline KLR-9435 a & $\operatorname{lan} 10$ & 29 & 38 & Male & & Femur & $\mathrm{CO}$ \\
\hline KLR-9435 a & $\operatorname{lan} 10$ & 29 & 38 & Male & & Femur & $\mathrm{TR}$ \\
\hline KLR-9436 & $\operatorname{lan} 11$ & 50 & 65 & Male & $\mathrm{TBC}$ & Femur & $\mathrm{CO}$ \\
\hline KLR-9437 a & $\operatorname{lan} 13$ & 40 & 50 & Male & Syph. & Femur & $\mathrm{CO}$ \\
\hline KLR-9437 a & $\operatorname{lan} 13$ & 40 & 50 & Male & Syph. & Femur & TR \\
\hline KLR-9438 & $\operatorname{lan} 14$ & 40 & 55 & Male & & Femur & $\mathrm{CO}$ \\
\hline KLR-9438 & $\operatorname{lan} 14$ & 40 & 55 & Male & & Femur & $\mathrm{TR}$ \\
\hline KLR-9439 & $\operatorname{lan} 15$ & 45 & 65 & Male & & Femur & $\mathrm{CO}$ \\
\hline KLR-9439 & $\operatorname{lan} 15$ & 45 & 65 & Male & & Femur & TR \\
\hline KLR-9440 a & $\operatorname{lan} 16$ & 40 & 50 & Male & Syph. & Femur & $\mathrm{CO}$ \\
\hline KLR-9440 a & $\operatorname{lan} 16$ & 40 & 50 & Male & Syph. & Femur & TR \\
\hline KLR-9441 & $\operatorname{lan} 20$ & 3 & 4 & Male & & Femur & $\mathrm{CO}$ \\
\hline KLR-9442 & $\operatorname{lan} 21$ & 26 & 33 & Male & & Femur & $\mathrm{CO}$ \\
\hline KLR-9442 & $\operatorname{lan} 21$ & 26 & 33 & Male & & Femur & TR \\
\hline KLR-9443 & $\operatorname{lan} 22$ & 25 & 38 & Male & & Femur & $\mathrm{CO}$ \\
\hline KLR-9443 & $\operatorname{lan} 22$ & 25 & 38 & Male & & Femur & TR \\
\hline KLR-9444 & $\operatorname{lan} 23$ & 30 & 40 & Female & & Femur & $\mathrm{CO}$ \\
\hline KLR-9445 & $\operatorname{lan} 24$ & 43 & 57 & Male & & Femur & $\mathrm{CO}$ \\
\hline KLR-9445 & $\operatorname{lan} 24$ & 43 & 57 & Male & & Femur & TR \\
\hline KLR-9446 & $\operatorname{lan} 25$ & - & - & Female & & Femur & $\mathrm{CO}$ \\
\hline KLR-9446 & $\operatorname{lan} 25$ & - & - & Female & & Femur & TR \\
\hline
\end{tabular}

The columns designate: laboratory numbers; archaeological field numbers; estimated minimum and maximum age at death; sex; diseases (Syph. = syphilis, $\mathrm{TBC}=$ Tuberculosis); bone element sampled; type of tissue $\mathrm{CO}=$ cortical, $\mathrm{TR}=$ trabecular

sample weighing ca. $40 \mathrm{mg}$ was dissolved in a mixture of $4 \mathrm{~mL}$ of $65 \% \mathrm{HNO}_{3}$ and $2 \mathrm{~mL} 30 \% \mathrm{H}_{2} \mathrm{O}_{2}$, both of ICPMS-grade (TraceSELECT ${ }^{\circledR}$ Fluka). The digestion took place in new, sealed polystyrene containers, which were left on a shaking table for $24 \mathrm{~h}$ at room temperature (ca. $20{ }^{\circ} \mathrm{C}$ ). The excess hydrogen peroxide was driven away by adding $0.67 \mathrm{~mL} 38 \%$ ICP-MS-grade $\mathrm{HCl}$ (PlasmaPURE Plus ${ }^{\circledR}$ SCP Science). The samples were then diluted to $10 \mathrm{~mL}$ with Milli-Q water and filtered through $0.45 \mu \mathrm{m}$ PVDF Q-Max disposable filters. The samples were then divided in halves, and one half was further diluted and used for ICP-MS, while the other half was used for CVAAS. The solutions were stored at $+4{ }^{\circ} \mathrm{C}$ until the analyses were performed a day or two later. The analyses were carried out on a Bruker ICP-MS 820, equipped with a frequency-matching RF generator and a Collision Reaction Interface (CRI), operating with either helium or hydrogen as skimmer gas. The basic parameters were as follows: radiofrequency power $1.40 \mathrm{~kW}$, plasma gas flow $15.50 \mathrm{~L} \mathrm{~min}^{-1}$; auxiliary gas flow $1.65 \mathrm{~L} \mathrm{~min}^{-1}$; sheath gas flow $0.12 \mathrm{~L} \mathrm{~min}^{-1}$; nebulizer gas flow $1.00 \mathrm{~L} \mathrm{~min}^{-1}$. The $\mathrm{CRI}$ reaction system was activated for $\mathrm{Fe}$ and $\mathrm{Cu}$ because of interferences with polyatomic species produced by a combination of isotopes coming from the argon plasma, reagents, or the matrix. A mixture of ${ }^{45} \mathrm{Sc},{ }^{89} \mathrm{Y}$, and ${ }^{159} \mathrm{~Tb}$ was used as internal standard added to all analyses. The following isotopes were measured without skimmer gas: ${ }^{44} \mathrm{Ca},{ }^{55} \mathrm{Mn},{ }^{88} \mathrm{Sr},{ }^{137} \mathrm{Ba}$, and ${ }^{208} \mathrm{~Pb} .{ }^{56} \mathrm{Fe}$ was measured with hydrogen as skimmer gas. ${ }^{63} \mathrm{Cu}$ was analysed with helium as skimmer gas. The dwell time on each peak was $30 \mathrm{~ms}$. 
Table 2 List of individuals investigated from the Hardenberg Chapel

\begin{tabular}{|c|c|c|c|c|c|c|}
\hline Lab. no. & Sample & Age $\min$ & Age max & Sex & Bone & Tissue \\
\hline KLR-10440a & HB 125/75 & 50 & 70 & Female & Right femur & $\mathrm{CO}$ \\
\hline KLR-10441a & HB 128/75 & 20 & 30 & Female & Left humerus & $\mathrm{CO}$ \\
\hline KLR-10441b & HB 128/75 & 20 & 30 & Female & Left humerus & TR \\
\hline KLR-10442a & HB 86/75 & 40 & 50 & Male & Left femur & $\mathrm{CO}$ \\
\hline KLR-10442b & HB 86/75 & 40 & 50 & Male & Left femur & TR \\
\hline KLR-10443a & HB 126/75 & 37 & 48 & Male & Right femur & $\mathrm{CO}$ \\
\hline KLR-10443b & HB 126/75 & 37 & 48 & Male & Right femur & TR \\
\hline KLR-10444a & HB 76/75 & 38 & 48 & Female & Right femur & $\mathrm{CO}$ \\
\hline KLR-10445a & HB 127/75 & 45 & 65 & Male & Right humerus & $\mathrm{CO}$ \\
\hline KLR-10445b & HB 127/75 & 45 & 65 & Male & Right humerus & TR \\
\hline KLR-10446a & HB 137/75 & 25 & 38 & Male & Right tibia & $\mathrm{CO}$ \\
\hline KLR-10446b & HB 137/75 & 25 & 38 & Male & Right tibia & $\mathrm{TR}$ \\
\hline
\end{tabular}

The columns designate: laboratory numbers; archaeological field numbers; estimated minimum and maximum age at death; sex; bone element sampled; tissue type $(\mathrm{CO}=$ cortical, $\mathrm{TR}=$ trabecular $)$

There were made 5 replicate analyses of each sample and each replicate consisted of 30 mass scans. Multi-element calibration standards were prepared in $1 \% \mathrm{HNO}_{3}$ at 6 different concentrations $\left(0,1,10,20,100\right.$, and $\left.200 \mu \mathrm{g} \mathrm{L}^{-1}\right)$, but for each element only 3 standards were selected to fit the appropriate concentration range found in the sample. For the main element Ca three standards of 100, 200, and $250 \mu \mathrm{g} \mathrm{L}^{-1}$ were used. Each day an in-house standard sample manufactured from a homogenized medieval bone was analysed along with the samples in order to monitor the overall performance. Together with the samples was also analysed an international standard, NIST SRM-1486, a modern bone sample. For the modern samples more $\mathrm{H}_{2} \mathrm{O}_{2}$ had to be added in order to cope with its higher collagen content. The average overall relative standard deviation (RSD) of the reported element concentrations were ( $1 \sigma$ expressed in $\%$ of the concentration): Ca: 1.6; Mn: 0.9; Fe: 6.4; Cu: 4.5; Sr: 0.7; Ba: 0.7; and $\mathrm{Pb}: 0.7$. Concentrations below the LOQ (limit of quantification) are reported as $<\mathrm{LOQ}$. The LOQ is calculated as 10 times the standard deviation over the detection limit, where the standard deviation is calculated as a mean of the standard deviations measured over a ca. half-year period with one or two weekly runs. The LOQ's were: Ca: $40.7 \mu \mathrm{g} \mathrm{g}^{-1}$; Mn: $0.51 \mu \mathrm{g} \mathrm{g}^{-1}$; Fe: $13.5 \mu \mathrm{g} \mathrm{g}^{-1}$; $\mathrm{Cu}: 2.56 \mu \mathrm{g} \mathrm{g}^{-1}$; Sr: $0.72 \mu \mathrm{g} \mathrm{g}^{-1}$; Ba: $0.49 \mu \mathrm{g} \mathrm{g}^{-1}$; and $\mathrm{Pb}$ :

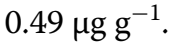

\section{CV-AAS}

Mercury was measured by cold vapour atomic absorption spectrometry on a dedicated mercury analyser, a Flow Injection Mercury System (FIMS-400) manufactured by PerkinElmer and equipped with an S10 autosampler. This system featured a better detection limit for $\mathrm{Hg}$ than the ICP-MS, which tends to be overloaded with $\mathrm{Hg}$ from the continuous daily analyses of bones, some of which high in $\mathrm{Hg}$. Two hours prior to analysis $1 \mathrm{~mL}$ of concentrated $\mathrm{KMnO}_{4}$ was added to $5 \mathrm{~mL}$ of sample in order to maintain the $\mathrm{Hg}$ in solution on ionic form. The sample was then diluted to $20 \mathrm{~mL}$. In the reaction chamber of the FIMS-400 the $\mathrm{Hg}$ was released as vapour by adding $\mathrm{NaBH}_{4}$. The analyser was operated in the continuous flow mode. An in-house human bone standard was dissolved daily together with the bone samples and included in the daily runs in order to monitor any drift in the systems. The overall standard deviation, i.e. the standard deviation including measurement, reproducibility and dilution, was estimated to be ca. $\pm 3.0 \%$ (RSD at $1 \sigma$ ) for $\mathrm{Hg}$, and the LOD (Limit Of Detection) was ca. $1.5 \mathrm{ng} \mathrm{g}^{-1}$ for a human bone sample of ca. $20 \mathrm{mg}$, and the LOQ (Limit Of Quantification) was calculated to $8.72 \mathrm{ng} \mathrm{g}^{-1}$ based on daily measurements of the in-house standard sample over half a year.

\section{Estimation of age and sex}

Sex estimation was made as described by Buikstra and Ubelaker [94] evaluating the morphology of the pelvic bones and the cranium. Furthermore, the robustness and the size of the post cranial skeletons were considered [95].

Age at death in adults was estimated according to the Experience-based method described in Milner and Boldsen [96] and Milner et al. [97]. The method utilizes degenerative and age-related changes in a large number of bones in the entire skeleton. Each skeleton was given an estimated age range of minimum and maximum age at death. 


\section{Results}

The results are listed in Additional file 1: Table S1, which lists the concentrations of $\mathrm{Ca}, \mathrm{Mn}, \mathrm{Fe}, \mathrm{Cu}, \mathrm{Sr}, \mathrm{Ba}, \mathrm{Hg}$, and $\mathrm{Pb}$ (in wt $\%, \mu \mathrm{g} \mathrm{g}^{-1}$ or $\mathrm{ng} \mathrm{g}^{-1}$ ) one standard deviation in (wt\%, $\mu \mathrm{g} \mathrm{g}^{-1}$ or $n g \mathrm{~g}^{-1}$ ). Also listed are the results of the analyses of the SRM NIST-1486 Bone meal and an inhouse medieval human bone standard.

\section{Statistical evaluation}

The statistical evaluation was conducted on the compact bone samples of the 72 individuals. The arithmetic mean and the relative standard deviations (RSD) are listed in Table 3, sorted according to their country (set) and burial locations (sub-set). The values below LOQ were replaced by the LOQ value itself for the calculation of the statistical parameters and the computation of the Principal Component Analysis (PCA).

In the Italian sample set, two individuals showed very high concentrations for Mn and Fe (KLR-9441/Ian20 and KLR-9474/USD459). Two other samples exhibited very high Fe concentrations (KLR-9443/Ian22 and KLR9446/ Ian25). These values have been discarded from the calculations of the statistical index of Fe and $\mathrm{Mn}$ in Table 3 because of the distortion they cause. For the two Italian sub-sets, larger variations were found for the distributions of $\mathrm{Mn}, \mathrm{Fe}$, and $\mathrm{Pb}$ (RSD of the mean >0.6). The elemental concentrations of the individuals from the Iannelli crypt also exhibited a high variation in $\mathrm{Cu}$ and $\mathrm{Hg}$ (RSD of the mean $>0.8$ ), while the same elements showed a lower variation amongst the friars and townspeople.

In the Danish sample set one individual showed very high Fe and Mn concentrations (KLR-8536) and was therefore discarded from the statistical calculations. For the two sub-sets of Danish samples, high variations were found for $\mathrm{Mn}$ and $\mathrm{Cu}$ (RSD of the mean >0.6) and to a lesser extend for Fe. A high variation was also observed for the $\mathrm{Hg}$ concentrations in the Hardenberg crypt bones (RSD of the mean $>1$ ).

Two Kruskal-Wallis ANOVA analyses were performed on the Italian and Danish sample sub-sets without the discarded outliers of Fe and Mn, and only for cortical tissues. The results are summed-up in Table 4. In the Italian sample set the distributions of all the elements are statistically different between the individuals from the Iannelli crypt and the ones buried in the cloister walk. In the Danish sample set, all the elements except Fe, Mn, and $\mathrm{Hg}$ are statistically different between the Hardenberg crypt and the individuals interred in the cloister walk.

\section{Principal component analysis}

Two PCA analyses on Spearman ranks correlation matrices were computed on the values from the cortical bone samples of the 72 individuals: one for the Italian individuals and one for the Danish ones. For the Italian skeletons $(\mathrm{n}=51)$ the three first principal components (also called Varifactors after the Varimax transformation) accounted for $81 \%$ of the variance (Table 5). The first principal component, PC-1, explained $36 \%$ of the variance and showed high positive loadings for $\mathrm{Ca}, \mathrm{Sr}$, and $\mathrm{Ba}$ and low negative loadings for $\mathrm{Cu}$ and $\mathrm{Hg}$. PC-2 explained $29 \%$ of the variance and was characterised by high positive loadings of $\mathrm{Mn}, \mathrm{Fe}, \mathrm{Cu}$, and $\mathrm{Hg}$. The third principal component, PC-3, explained $17 \%$ of the variance. PC-3 showed a high positive loading for $\mathrm{Pb}$ and moderate positive loading for Fe.

For the Danish skeletons $(n=21)$, the four first principal components accounted for $91 \%$ of the variance (Table 5). PC-1 explained $35 \%$ of the total variance and showed high or moderate positive loadings for $\mathrm{Ca}$ and $\mathrm{Sr}$, and a moderate positive loading for $\mathrm{Ba}$ and $\mathrm{Cu}$. PC-2 explained $20 \%$ of the variance and was characterized by high positive loadings for $\mathrm{Mn}$ and Fe. PC-3 explained $15 \%$ of the variance and it showed high positive loading for $\mathrm{Hg}$. PC-4 explains $20 \%$ of the variance and exhibited high negative loading for $\mathrm{Pb}$.

The results of the Kruskal-Wallis ANOVA applied to the PCA factors showed that there are statistically significant differences in the coordinates of the bones from the two noble families and the respective townspeople for the Italian and Danish skeletons.

\section{Discussion}

\section{Strontium and barium}

The concentration of $\mathrm{Sr}$ is plotted versus the concentration of $\mathrm{Ba}$ in Fig. 3a for the cortical tissue samples from the Italian individuals, and in Fig. $3 \mathrm{~b}$ for the Danish individuals. The patterns seen in Fig. $3 \mathrm{a}, \mathrm{b}$ are very similar: the individuals buried in the crypts under the private chapels of the noble families are low in both $\mathrm{Sr}$ and $\mathrm{Ba}$ compared to the friars or villagers buried in the adjacent cloister walks, and this is the case for both Montella and Svendborg. As mentioned above, variations in $\mathrm{Sr}$ - and Ba-concentrations can either be due to differences in provenance or determined by changes in dietary habits or the individuals. In this case it is likely that the observed differences reflect a difference in dietary habits between noble families and the friars or villagers. It could well be due to a diet high in meat in the Iannelli and Hardenberg families, who both had a high social status and presumably the ability to afford meat as a part of their daily diet $([19,89]$, see also Fig. 8 in [32]).

Another less likely possibility is that the differences in $\mathrm{Sr}$ and $\mathrm{Ba}$ concentrations are caused by the difference in age of the burials, both private chapels are from the 


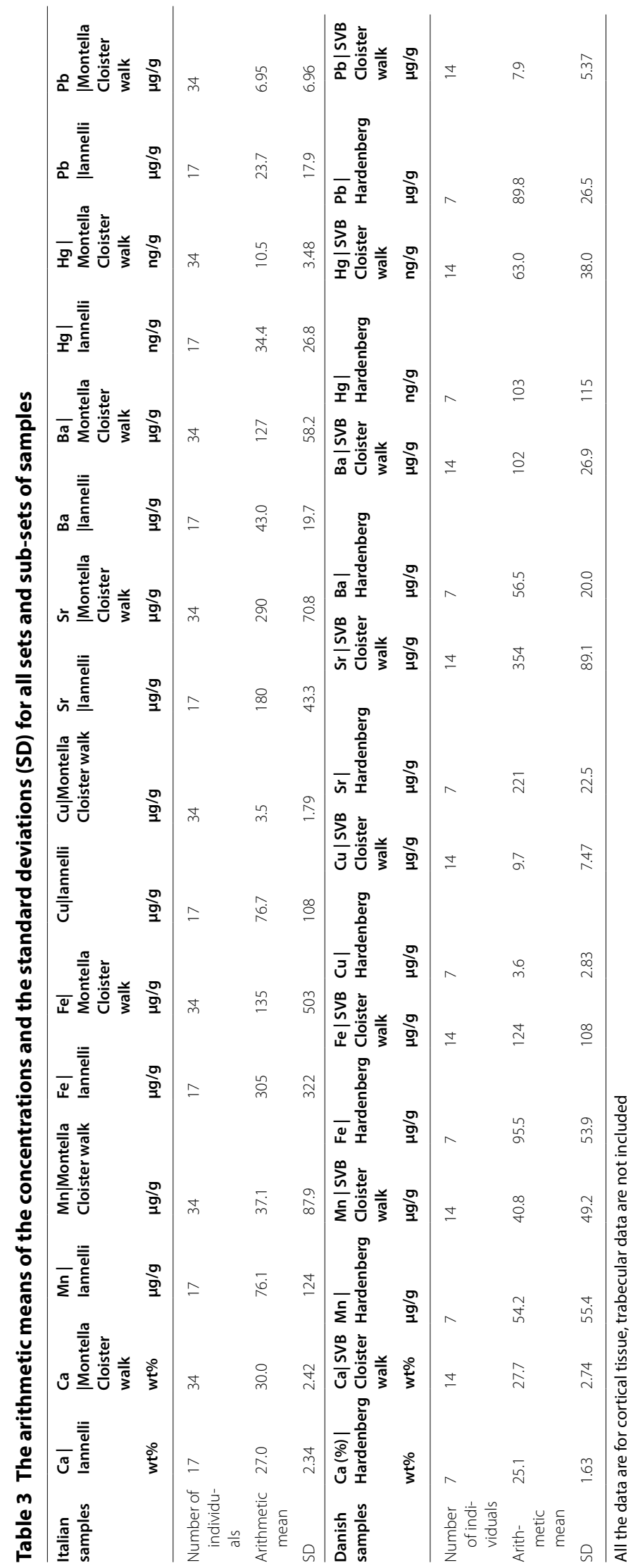


Table 4 The results of the Kruskal-Wallis ANOVA analyses of the two sets and two sub-sets of individuals

\begin{tabular}{|c|c|c|c|}
\hline \multicolumn{2}{|l|}{ Italian samples } & \multicolumn{2}{|l|}{ Danish samples } \\
\hline Elements & KW p-value & Elements & KW p-value \\
\hline $\mathrm{Ca}(\mathrm{n}=51)$ & 0.000 & $\mathrm{Ca}(\mathrm{n}=21)$ & 0.021 \\
\hline$M n(n=49)$ & 0.002 & $\operatorname{Mn}(n=20)$ & 0.452 \\
\hline $\mathrm{Fe}(\mathrm{n}=47)$ & $<0.0001$ & $\mathrm{Fe}(\mathrm{n}=20)$ & 0.782 \\
\hline $\mathrm{Cu}(\mathrm{n}=51)$ & $<0.0001$ & $\mathrm{Cu}(\mathrm{n}=21)$ & 0.022 \\
\hline $\operatorname{Sr}(n=51)$ & $<0.0001$ & $\operatorname{Sr}(n=21)$ & 0.002 \\
\hline $\mathrm{Ba}(\mathrm{n}=51)$ & $<0.0001$ & $\mathrm{Ba}(\mathrm{n}=21)$ & 0.002 \\
\hline $\mathrm{Hg}(\mathrm{n}=51)$ & $<0.0001$ & $\mathrm{Hg}(\mathrm{n}=21)$ & 0.551 \\
\hline $\mathrm{Pb}(\mathrm{n}=51)$ & $<0.0001$ & $\mathrm{~Pb}(\mathrm{n}=21)$ & 0.000 \\
\hline Factors $(n=51)$ & KW p-value & Factors $(n=21)$ & KW p-value \\
\hline D1 & $<0.0001$ & D1 & 0.881 \\
\hline D2 & 0.000 & D2 & 0.823 \\
\hline \multirow[t]{2}{*}{ D3 } & 0.001 & D3 & 0.654 \\
\hline & & D4 & 0.263 \\
\hline
\end{tabular}

Only cortical tissue samples. Numbers of data points in parenthesis. Value in italics are below the p-value $(<0.05)$

Value in italics are below the $p$-value $(<0.05)$

Table 5 Varifactor loadings for the two PCA performed on the Italian and the Danish samples

\begin{tabular}{|c|c|c|c|c|c|c|c|c|}
\hline \multicolumn{4}{|c|}{ PCA of Italian samples_-Varifactors loadings } & \multicolumn{5}{|c|}{ PCA of Danish samples_-Varifactors loadings } \\
\hline & PC-1 & PC-2 & PC-3 & & PC-1 & PC-2 & PC-3 & PC-4 \\
\hline $\mathrm{Ca}$ & 0.882 & -0.146 & 0.139 & $\mathrm{Ca}$ & 0.959 & -0.046 & -0.031 & -0.035 \\
\hline $\mathrm{Mn}$ & 0.095 & 0.881 & 0.009 & $\mathrm{Mn}$ & -0.020 & 0.888 & -0.134 & -0.194 \\
\hline $\mathrm{Fe}$ & -0.034 & 0.656 & 0.541 & $\mathrm{Fe}$ & 0.060 & 0.809 & 0.252 & 0.307 \\
\hline $\mathrm{Cu}$ & -0.370 & 0.755 & 0.256 & $\mathrm{Cu}$ & 0.730 & 0.275 & 0.398 & 0.389 \\
\hline $\mathrm{Sr}$ & 0.918 & -0.037 & -0.305 & $\mathrm{Sr}$ & 0.919 & -0.082 & -0.054 & 0.306 \\
\hline $\mathrm{Ba}$ & 0.868 & -0.143 & -0.337 & $\mathrm{Ba}$ & 0.675 & 0.297 & 0.090 & 0.618 \\
\hline $\mathrm{Hg}$ & -0.474 & 0.720 & -0.084 & $\mathrm{Hg}$ & 0.008 & 0.010 & 0.984 & -0.005 \\
\hline $\mathrm{Pb}$ & -0.273 & 0.066 & 0.859 & $\mathrm{~Pb}$ & -0.194 & 0.063 & 0.015 & -0.929 \\
\hline
\end{tabular}

Values in italics show the higher squared cosine for each element

17th-18th centuries, whereas the majority of burials in the cloister walks are in both cases medieval; in Svendborg probably predating the protestant reformation in 1536, and in Montella mostly before 1500 according to a large number of radiocarbon datings reported [2]. The time differences are at least 75 years and 100 years difference in Svendborg and Montella, respectively. These time differences are, however, not considered large enough to skew the comparison in a major way.

If we focus on the $\mathrm{Sr}$ versus $\mathrm{Ba}$ of the compact tissues of the individuals from the two crypts, it is seen that there is an overlap between the concentrations from the Hardenberg and the Iannelli families. Both populations show a positive correlation between $\mathrm{Sr}$ and $\mathrm{Ba}$ concentrations, and both populations exhibit very low and overlapping $\mathrm{Sr}$ and $\mathrm{Ba}$ concentrations, although the Iannelli individuals have a little lower concentrations of both $\mathrm{Sr}$ and $\mathrm{Ba}$ than the Hardenberg individuals. It could be a coincidence that the amounts of bioavailable $\mathrm{Sr}$ and $\mathrm{Ba}$ were similar in Montella and Svendborg, but it is a more likely interpretation that the $\mathrm{Sr}$ and Ba concentrations for these two noble families are determined by their diet, probably very high in animal meat, and that the fractions of animal meat consumed have been somewhat similar resulting in the observed overlap.

\section{Mercury and lead}

There are other similarities between the normal population and the noble families in Montella and Svendborg. In 

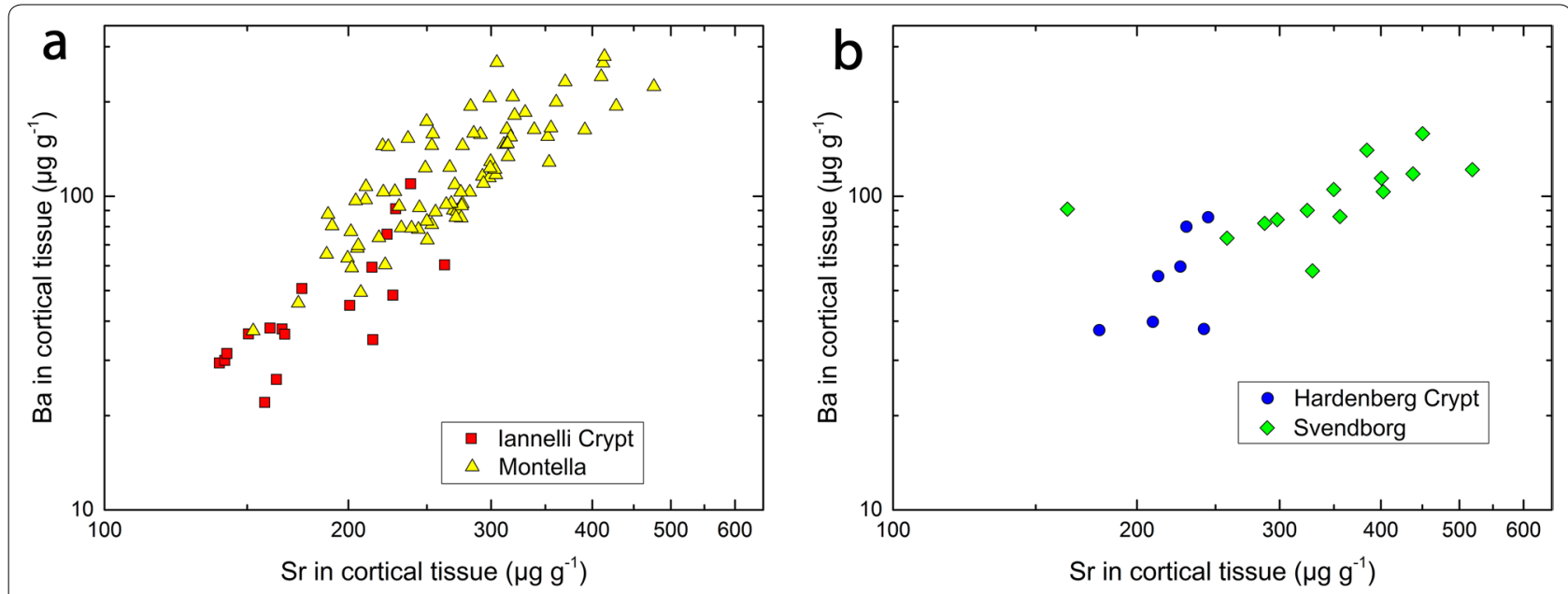

Fig. 3 The concentration of $\mathrm{Ba}$ (in $\mu \mathrm{g} \mathrm{g}^{-1}$ ) as a function of $\mathrm{Sr}$ (also in $\mu \mathrm{g} \mathrm{g}^{-1}$ ) in cortical tissue. a Data from Montella, Italy. The individuals interred in the lannelli crypt (red squares) and the individuals from the cloister walk (yellow pyramids); b data from Svendborg, Denmark. The individuals interred in the Hardenberg crypt (blue circles) and the individuals from the cloister walk (green diamonds)
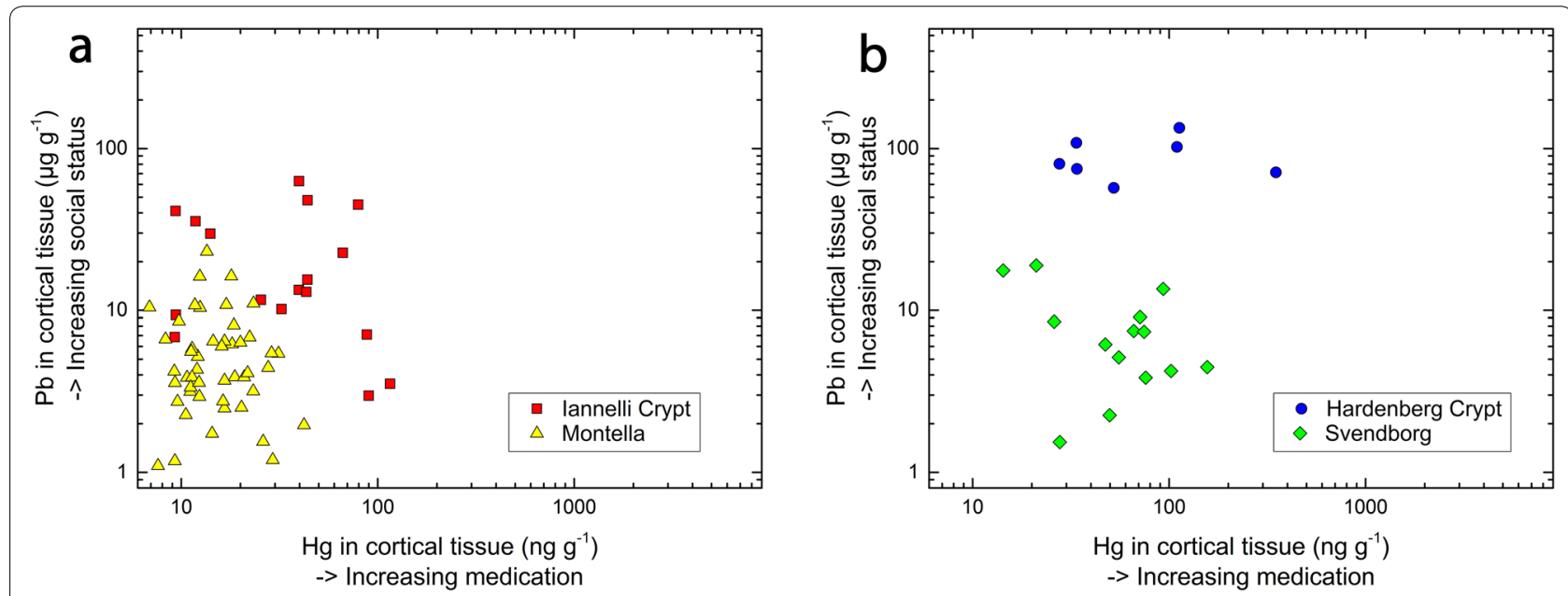

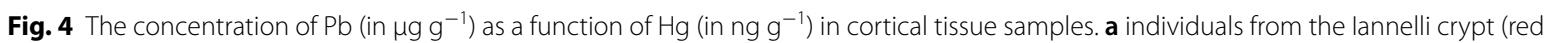
squares) and the friary cloister walk (yellow pyramids); b individuals from the Hardenberg crypt (blue circles) and the individuals excavated from the cloister walk (green diamonds)

Fig. 4 is shown the concentrations of $\mathrm{Pb}$ versus $\mathrm{Hg}$, and it can be seen that both noble families are higher in $\mathrm{Pb}$-concentrations than their respective comparative material from the cloister walks. The individuals from the Iannelli crypt are on average a factor of 3.4 higher in $\mathrm{Pb}$ concentrations than the individuals interred in the cloister walk, whereas the individuals from the Hardenberg crypt are about a factor of 11.4 higher in $\mathrm{Pb}$ concentrations compared to the friars and townspeople from Svendborg (see Table 3). The enrichment factors for $\mathrm{Hg}$ are 3.3 and 1.6 for Iannelli and Hardenberg respectively, but for $\mathrm{Hg}$ there are large variations indicating that some individuals have received $\mathrm{Hg}$ while others not. However, considering the averages listed in Table 3, there are on average more $\mathrm{Hg}$ in the noble families even though there is also a great deal of overlap in the distributions.

The most likely exposure-way to $\mathrm{Hg}$ for the noble families is through medication [2, 43, 46, 58]. It can be seen from Fig. 4a that seven individuals (five visible on the plot, KLR-9429, KLR-9430a, KLR-9432, KLR-9435a, KLR-9440a, plus two individuals below LOQ) from the Iannelli crypt have very low $\mathrm{Hg}$-concentrations (less than $12 \mathrm{ng} \mathrm{g}^{-1}$ ), whereas 12 individuals have Hg-concentrations in the cortical tissue higher than the highest of 
the individuals interred in the cloister walk $\left(22 \mathrm{ng} \mathrm{g}^{-1}\right)$. It therefore seems a viable interpretation that a handful of the Iannelli family members were exposed to Hg-containing medicine whilst none of the friars and villagers were exposed to $\mathrm{Hg}$.

Contrary to Montella, no significant differences were observed in the distributions of $\mathrm{Hg}$ in Svendborg-noble family and friars/townspeople alike seem to have had equal access to $\mathrm{Hg}$-containing medicine (Fig. 4a), but none of them were highly exposed.

\section{Lead and copper}

The main sources for both $\mathrm{Pb}$ and $\mathrm{Cu}$ are probably cooking utensils [32, 39, 46, 69-71, 91, 98]. Lead was used throughout medieval Europe for glazing ceramics; a glaze which could release $\mathrm{Pb}^{2+}$ ions into the foodstuff if the food had a low $\mathrm{pH}$. Copper was utilised in the medieval period and post-modern time as a very abundant material for large cooking pots and food containers in wealthy homes [90]. The estimated time-period for the burials in both chapels are 17th to 18th century, where the use of $\mathrm{Cu}$ utensils is expected to have been widespread in large parts of both societies. In Fig. 5 is shown the concentration of $\mathrm{Pb}$ as a function of the concentration of $\mathrm{Cu}$ in cortical tissue, which shows that the Hardenberg individuals have 3.8 times higher Pb-concentrations than the Iannelli family members, while the Iannelli individuals are a factor of 21 times higher in $\mathrm{Cu}$ concentrations compared to the Hardenberg individuals. It therefore seems a plausible interpretation that $\mathrm{Cu}$ utensils were not introduced in the kitchen of the Hardenberg's whereas they were indeed present in the kitchen of the Iannelli family. The exposure to $\mathrm{Pb}$ was more similar in the two places, only the
Hardenberg family members were slightly more exposed to $\mathrm{Pb}$ than the Iannelli's.

As for the effect of age, it seems possible that $\mathrm{Pb}$ accumulated in cortical tissue with increasing age in the noble family members from the Iannelli crypt (red square points in Fig. 6). It is not possible to determine if such an age-dependant effect is also present in individuals from the Hardenberg crypt in Svendborg, because only middle-aged adults from 32 to 50 years at the time of death have been excavated here. A number of reasons for such a chronic exposure to $\mathrm{Pb}$ can be thought of: lead glazed ceramics, pewter or even pure lead utensils in the kitchen, lead tiled roofs possibly exposing the drinking water, or the intake of wine with added lead acetate, which has the property to arrest fermentation and souring [99]. The region of Irpinia, where Montella is situated, was famous for its good wine, which makes the latter option a possibility. However, no such increase of $\mathrm{Pb}$ concentration with age was seen in medieval and post-medieval Horsens (see Fig. 4 in [46]), where the range of $\mathrm{Pb}$ concentrations were almost similar to the Iannelli individuals. It therefore remains a possibility that the correlation between age at death and $\mathrm{Pb}$ concentration in cortical bone for the Iannelli family members is a coincidence.

Finally, there is the possibility that $\mathrm{Cu}$ and $\mathrm{Pb}$ can be derived from posthumous diagenetic processes. Statistically speaking there is a correlation between $\mathrm{Fe}$ on one side and $\mathrm{Cu}$ and to some degree also $\mathrm{Pb}$ on the other side for the Svendborg samples, which could be due to an overprint of a diagenetic effect for $\mathrm{Cu}$ and also but less likely for $\mathrm{Pb}$. In the Iannelli individuals no correlations were seen between $\mathrm{Fe}$ and $\mathrm{Cu}$, nor between $\mathrm{Fe}$ and $\mathrm{Pb}$,

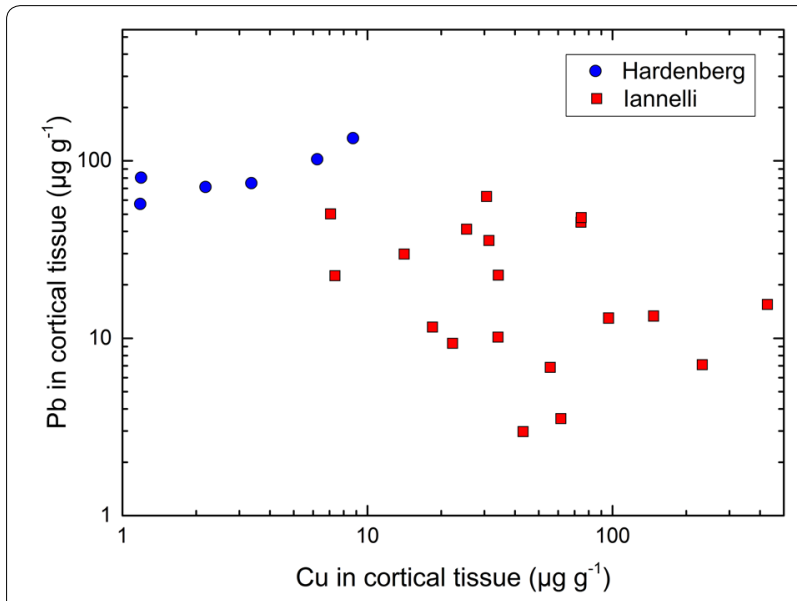

Fig. 5 The concentration of $\mathrm{Pb}$ (in $\mu \mathrm{g} \mathrm{g}^{-1}$ ) as a function of $\mathrm{Cu}$ (also in $\mathrm{\mu g} \mathrm{g}^{-1}$ ) in cortical tissue for the individuals interred in the lannelli crypt (red squares) and the individuals from the Hardenberg crypt (blue circles)

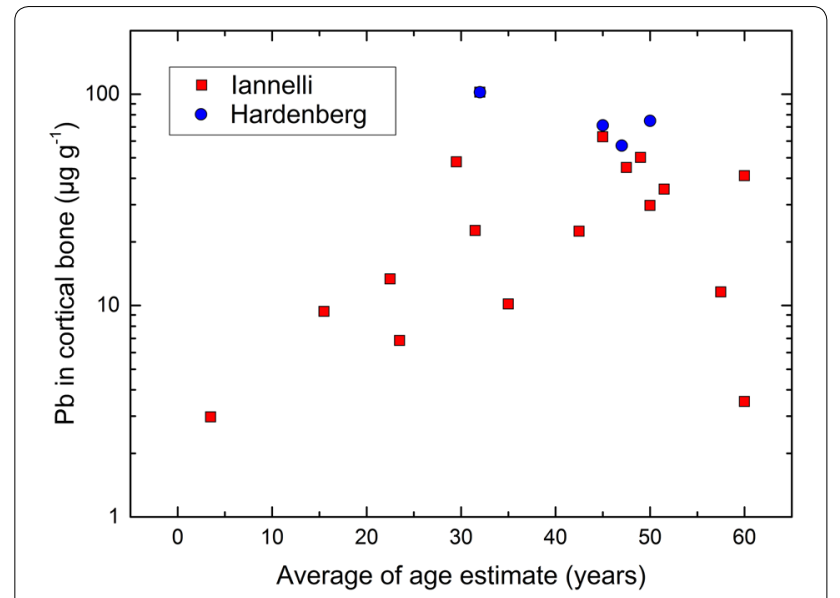

Fig. 6 The concentration of $\mathrm{Pb}\left(\right.$ in $\mu \mathrm{g} \mathrm{g}^{-1}$ ) as a function of the average estimated age at death; the lannelli individuals are shown with red squares and the Hardenberg individuals with blue circles 
and a digenetic origin of $\mathrm{Cu}$ or $\mathrm{Pb}$ in these individuals is not likely.

Iron, manganese and other elements-diagenesis or not? Iron and $\mathrm{Mn}$ are usually linked to diagenetic alteration in bones from the post-mortem environment [30, 68, 100-102]. Experiments carried out on buried animal bones showed unambiguously an increase of the $\mathrm{Fe}$ and $\mathrm{Mn}$ concentrations, even after short time in the soil [103, 104]. Values from modern cortical bone samples recorded in Poland and Taiwan $[105,106]$ showed that the average Fe concentrations in these bones were close to $100 \mu \mathrm{g} \mathrm{g}^{-1}$, but variations were seen with a maximum concentration value of above $1000 \mathrm{\mu g} \mathrm{g}^{-1}$.

In the present study the average concentration of $\mathrm{Mn}$ is close to $2 \mu \mathrm{g} \mathrm{g}^{-1}$ with a narrower variation range, the maximum value recorded is $20 \mu \mathrm{g} \mathrm{g}^{-1}$ (Table 3 ). In the PCA calculated on the two sets of samples from Italy and Denmark Mn and Fe were both associated with the same principal components with strong positive loadings, suggesting the influence of a diagenetic process involving these two elements (Table 5 and Fig. 7). For the Danish samples, the PC1 versus PC2 plot (Fig. 7a) shows that most of the samples from Svendborg are located in the right side of the plot with positive PC1coordinates. This reflects higher concentrations of $\mathrm{Ca}$, $\mathrm{Sr}, \mathrm{Ba}$, and $\mathrm{Cu}$. PC2 which is mainly influenced by Fe and Mn, does not discriminate the two sub-sets of samples. The PC3 versus PC4 plot (Fig. 7b) shows that all the samples from the Hardenberg crypt are located towards the bottom of the plot with negative values of $\mathrm{PC} 4$, reflecting higher proportions of $\mathrm{Pb}$ in these samples. PC3 that mainly represent the variability of $\mathrm{Hg}$ does in this set of samples discriminate between the Svendborg and the Hardenberg individuals. In Fig. 7c is shown PC1 versus PC2 of the Italian samples. Here a trend is visible with the gathering of the Iannelli crypt samples in the left side of the plot, reflecting higher
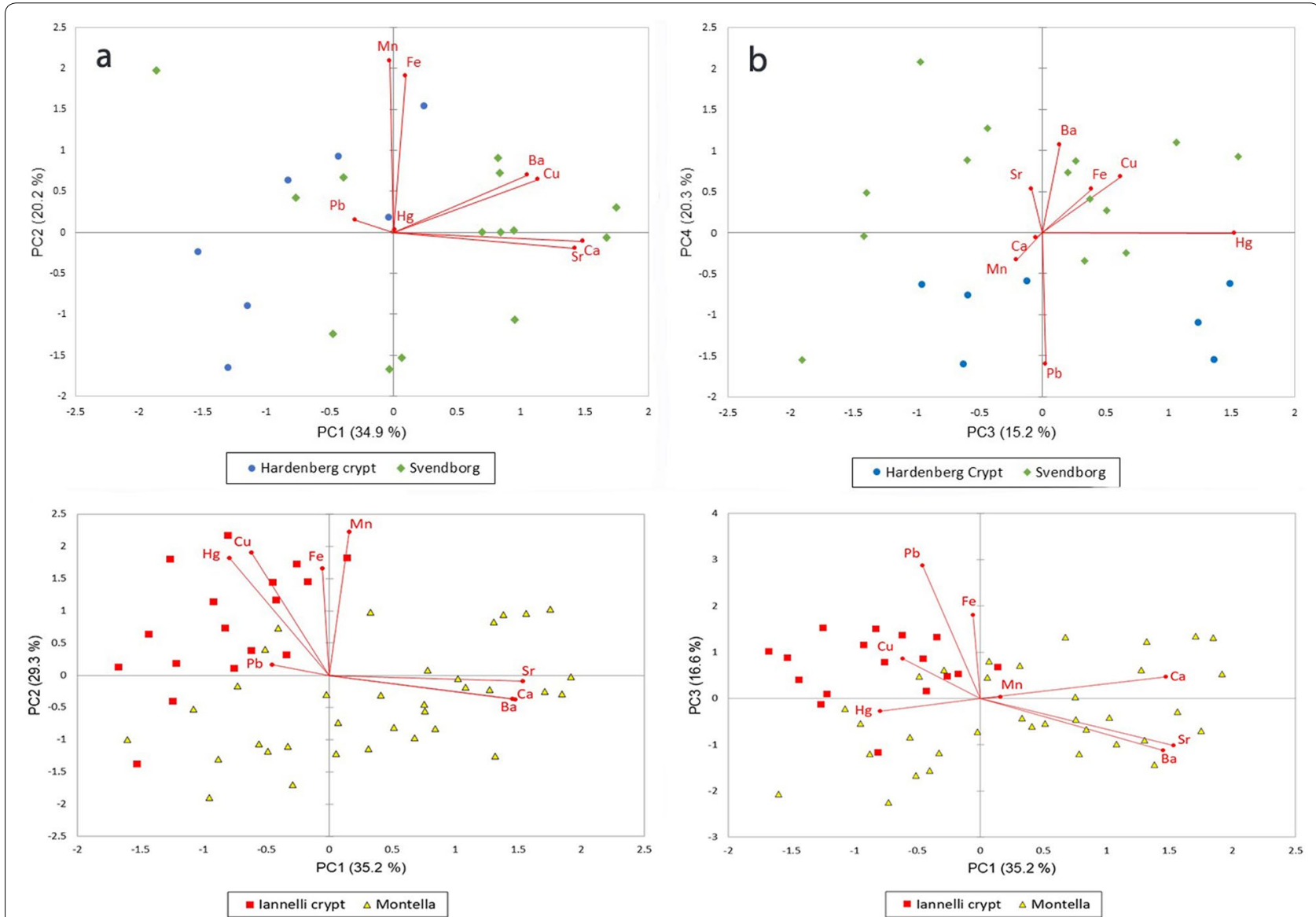

Fig. 7 The results of the PCA analysis. a PC1 versus PC2 for cortical tissue in the Hardenberg individuals and the Svendborg friars and townspeople; b PC3 versus PC4 for cortical tissue in the Hardenberg individuals and the Svendborg friars and townspeople; c PC1 versus PC2 for cortical tissue in the lannelli individuals and the Montella friars and townspeople; $\mathbf{d}$ PC1 versus PC3 for cortical tissue in the lannelli individuals and the Montella friars and townspeople 


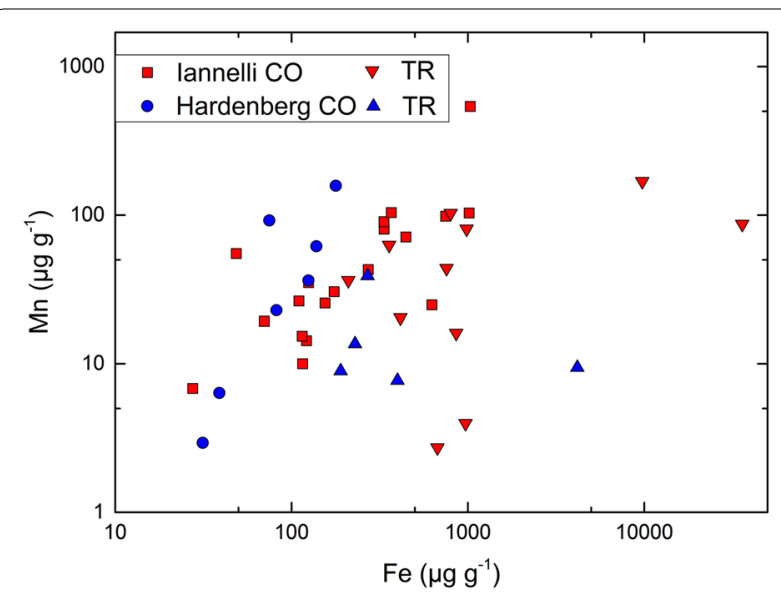

Fig. 8 The concentration of $\mathrm{Mn}$ (in $\mu \mathrm{g} \mathrm{g}^{-1}$ ) as a function of $\mathrm{Fe}$ (also in $\mu \mathrm{g} \mathrm{g}^{-1}$ ) in both cortical and trabecular tissue. Data from the individuals from the lannelli crypt, cortical tissue (red squares), trabecular tissue (red triangles). The individuals interred in the Hardenberg crypt, cortical tissue (blue circles) and trabecular tissue (blue pyramids top down)

values of $\mathrm{Cu}$ and $\mathrm{Hg}$. The influence of $\mathrm{Mn}$ and Fe are not very pronounced in these samples. A high proportion of the samples from Montella is located in the right side on the plot in Fig. 7c, reflecting higher values of $\mathrm{Sr}$ and $\mathrm{Ba}$. The $\mathrm{PC} 1$ versus $\mathrm{PC} 3$ plot in Fig. $7 \mathrm{~d}$ shows a very similar dispersion of the data points, but here there are higher values of $\mathrm{Pb}$ in the Iannelli crypt samples.

The four PCA plots in Fig. 7 are fitting well with the Kruskal-Wallis tests results, showing that the eight elements measured can discriminate the two sub-sets of Italian samples while the Danish samples are not well discriminated by $\mathrm{Hg}$, Fe, and $\mathrm{Mn}$.

The coefficient of determination between $\mathrm{Fe}-\mathrm{Mn}$ are high for the Iannelli crypt samples $\left(R^{2}=0.70\right)$, while it is very low for the samples from the cloister walk of Montella $(<0.1)$. Many samples from the Montella cloister walk have low concentrations of $\mathrm{Mn}$ and $\mathrm{Fe}$, and they are in the range of what is to be expected in a modern non-interred population (mean values reported between 12 and $500 \mu \mathrm{g} \mathrm{g}^{-1}$ for Fe, and 0.1 and $5 \mu \mathrm{g} \mathrm{g}^{-1}$ for $\mathrm{Mn}$, see Table 3 in [102]). Interestingly, the samples with high Mn values $\left(>20 \mu \mathrm{g} \mathrm{g}^{-1}\right)$ do not also have high concentrations of Fe (Additional file 1: Table S1), while for the Montella cloister walk the samples with relatively high Fe concentrations have low Mn concentrations $\left(<20 \mu \mathrm{g} \mathrm{g}^{-1}\right)$. The two sub-sets therefore showed a different distribution pattern and higher mean values for Fe and $\mathrm{Mn}$ in the Iannelli crypt samples according to Kruskal-Wallis ANOVA (Table 4).
For the individuals from the Svendborg cloister walk and the Hardenberg crypt there is a moderate to strong correlation between $\mathrm{Fe}$ and $\mathrm{Mn}(0.8$ and 0.7 , respectively). The distributions of the two sub-set of samples from Denmark and Italy are quite similar and no significant differences were detected in the results of the Kruskal-Wallis ANOVA (Table 4). A scenario of the same type of diagenetic processes even with a limited co-enrichment of Fe and $\mathrm{Mn}$, can still be possible, where the groundwater transports the easily dissolvable $\mathrm{Fe}$ and $\mathrm{Mn}$ ions from an anoxic environment to a more oxidized one, where both $\mathrm{Fe}$ and $\mathrm{Mn}$ changes oxidation state and becomes a lot less solvable.

The final test lies in the trabecular tissue, which is more prone to diagenesis than the cortical. In Fig. 8 is plotted the Mn-concentration as a function of the Feconcentration for all individuals in both private crypts, and as expected the Fe concentration has a tendency to be higher in the trabecular tissues than in the cortical for both burial sites. There seems to be no systematic difference, however, between the Mn-concentrations in cortical and trabecular tissues, neither in the Iannelli individuals nor in the Hardenberg ones. Even though there are no clear signs of systematic diagenesis in the sites, it remains our interpretation, however, that at least for some of the individuals there are diagenetic overprints for Fe and Mn.

\section{Conclusions}

The present study reveals a distinct inventory of trace elements in two noble families from the 17th-18th Century buried in two private crypts in Italy and Denmark. The Sr- and Ba-concentrations are lower in the individuals of both noble families than in the comparative material consisting of friars and townspeople. This effect is ascribed to a difference in diet, which for the noble families could be rich in terrestrial meat. Lead was found to be higher in both noble families compared to the comparative material, which is in accordance with the interpretation of higher $\mathrm{Pb}$-concentrations indicating a higher social status. The lead could possibly also have a slight diagenetic overprint in Svendborg. It seems possible that the Iannelli individuals accumulated $\mathrm{Pb}$ with age, which is a peculiar observation. Copper concentrations are distinctly higher in the Iannelli individuals than in the Hardenberg family members, which points to the presence of $\mathrm{Cu}$ cooking pots in the kitchen of the Iannelli family and lack of such equipment in the kitchen of the Hardenberg's. Copper concentrations were also somewhat correlated with $\mathrm{Fe}$ concentrations for the Svendborg individuals, and there 
could therefore also be a slight diagenetic overprint for $\mathrm{Cu}$ here. Mercury seems to have been administered to some of the Iannelli family members, whereas this was not the case for the Hardenberg's.

\section{Supplementary information}

Supplementary information accompanies this paper at https://doi. org/10.1186/s40494-020-00407-x.

Additional file 1. The elemental concentrations in $\mu \mathrm{g} \mathrm{g}^{-1}$, except Ca which is reported in weight $\%$, and $\mathrm{Hg}$ reported in $\mathrm{ng} \mathrm{g}^{-1}$. One standard deviation represents $66 \%$ probability. $<$ LOQ mean that the concentration was below the limit of quantification.

\section{Abbreviations}

ANOVA: Analysis of variance; CRI: Collision reaction interface; CV-AAS: Cold vapour atomic absorption spectrometry; ICP-MS: Inductively coupled plasma mass spectrometry; LOD: Limit of detection; LOQ: Limit of quantification; PCA: Principal component analysis; RSD: Relative standard deviation; SD: Standard deviation.

\section{Acknowledgements}

We are indebted to the VELUX foundation for financial support to the OPHELIA project (32089), the EU Interreg Office for financial support to the project Bones4Culture (10/13122), and to the Det Frie Forskningsråd for Kultur og Kommunikation for financial support to the project TheCityDwellers (610700284B). Pia Klingenberg Haussmann is thanked for technical help in the laboratory. Frater Agnello Stoia is thanked for help throughout this project We would like also to thank Tommaso landelli Scorpione, descendent of Bernardino lannelli, for his help and permission to do the research.

\section{Authors' contributions}

Conceived and designed the experiments: KLR. Performed the chemical analyses: PI and LS. Acquired the anthropological data PT and MT. Analysed the data: KLR, TD, LS, and PI. Contributed as leading field archaeologists and with historical references SS, MT, and POT. Contributed to the anthropological and laboratory components of the work, including the interpretation of results and acquisition of references: KLR, TD, PT, SS, MT. Wrote the paper, with comments from other participants: KLR and TD. The paper was approved by all authors. All authors read and approved the final manuscript.

\section{Funding}

The present work has been funded by Velux Fonden (VELUX 32089); Det. Frie Forskningsråd (DFF_6107-00284); EU Interreg Office for financial support to the project Bones4Culture (10/13122).

\section{Availability of data and materials}

Data are available upon request from the authors.

\section{Ethics approval and consent to participate}

No permission was required as all sample material was acquired through archaeological excavations.

\section{Competing interests}

The authors declare that they have no competing interests.

\footnotetext{
Author details

${ }^{1}$ Cultural Heritage and Archaeometric Research Team (CHART), Department of Physics, Chemistry and Pharmacy, University of Southern Denmark, Campusvej 55, 5230 Odense M, Denmark. ${ }^{2}$ Geology \& Geochemistry Research Cluster, Faculty of Science, Vrije Universiteit, De Boelelaan 1085, 1081 HV Amsterdam, The Netherlands. ${ }^{3}$ Pontifical Institute of Christian Archaeology, Via Napoleone III, 1, 00185 Rome, Italy. ${ }^{4}$ Laboratory of Science and Techniques Applied to Archaeology, University Suor Orsola Benincasa, Via Santa Caterina da Siena 37, 80135 Naples, Italy. ${ }^{5}$ Abels Allé 82, 5250 Odense SV, Denmark. ${ }^{6}$ Vindeby Tværvej 30, 5700 Svendborg, Denmark.
}

Received: 31 March 2020 Accepted: 16 June 2020

Published online: 02 July 2020

\section{References}

1. Schiavone S. Convento di San Francesco a Folloni. 2005-2013 (Montella-AV), in Notizie scavi e lavori sul campo, Schede 2012-2013, a cura di Sergio Nepoti, Archeologia Medievale XL. 2013;294-297.

2. Torino M, Boldsen JL, Tarp P, Rasmussen KL, Skytte L, Nielsen L, Schiavone S, Terrasi F, Passariello I, Ricci P, Lubritto C. Convento di San Francesco a Folloni: the function of a Medieval Franciscan Friary seen through the burials. Herit Sci. 2015;3:27.

3. Kristensen HK. The Franciscan Friary of Svendborg, The Archaeology of Svendborg, Volume 6 (Ed. Jansen, HM). 1994; pp 110.

4. Kristensen HK. Klostre i det middelalderlige Danmark. Jysk Arkæologisk Selskabs Skrifter. 2013;79:500.

5. Pankowskaa A, Mildeb D, Bohunskáb J. Variation of Ba/Ca and Sr/Ca response in human hard tissue from archaeological series. Interdis Archaeol Nat sci archaeol. 2016;7:157-67.

6. Turekian KK, Kulp JL. Strontium content of human bones. Science. 1954;124:405-7.

7. Toots H, Voorhies MR. Strontium in fossil bones and reconstruction of food chains. Science. 1965;149:854-5.

8. Brown AB. Bone strontium as a dietary indicator in human skeletal populations. Contribut Geol Univ Wyom. 1974;13:47-8.

9. Sillen A, Kavanagh M. Strontium and paleodietary research: a review. Yearbook Phys Anthropol. 1982;25:67-90.

10. Price TD, Kavannagh M. Bone composition and the reconstruction of diet: examples from the Midwestern United States. Midcontinental J Archaeol. 1982;7:61-79.

11. Lambert JB, Simpson SV, Szpunar CB, Buikstra JE. Ancient human diet from inorganic analysis of bone. Acc Chem Res. 1982;17:298-305.

12. Burton JH, Price T, Middleton WD. Correlation of bone Ba/Ca and Sr/Ca due to biological purification of calcium. J Archaeol Sci. 1999;26:609-16.

13. Reynard B, Balter $V$. Trace elements and their isotopes in bones and teeth: diet, environments, diagenesis, and dating of archeological and paleontological samples. Palaeogeogr Palaeoclimatol Palaeoecol. 2014;416:4-16.

14. Balter V. Allometric constraints on $\mathrm{Sr} / \mathrm{Ca}$ and $\mathrm{Ba} / \mathrm{Ca}$ partitioning in terrestrial mammalian trophic chains. Oecologia. 2004;139:83-8.

15. Hancock RG, Grynpas MD, Pritzker KP. The abuse of bone analyses for arcaheological dietary studies. Archaeometry. 1989;31:169-79.

16. Radosevich SC. The Six Deadly Sins of Trace Element Analysis: A Case of Wishful Thinking in Science. In: Sanford MK, editor. Investigations of Ancient Human Tissue-Chemical Analyses in Anthropology. 1993. Amsterdam: Gordon and Breach Science Publishers.

17. Burton J, Price TD. The ratio of barium, to strontium as a paleodietary indicator of consumption of marine resources. J Archaeol Sci. 1990;1990(17):547-57.

18. Price TD, Manzanilla L, Middleton WD. Immigration and the Ancient City of Teotihuacan in Mexico: a study using strontium isotope ratios in human bone and teeth. J Archaeol Sci. 2000;27:903-13.

19. Burton $\mathrm{JH}$, Wright LE. Nonlinearity in the relationship between bone Sr/Ca and Diet: paleodietary implications. Am J Phys Anthropol. 1995;97:273-82

20. Price TD. Multi-element studies of diagenesis in prehistoric bone. In: Price TD, editor. The chemistry of prehistoric human bone. Cambridge: Cambridge University Press; 1989. p. 126-54.

21. Fabig A, Herrmann B. Trace elements in buried human bones: intrapopulation variability of $\mathrm{Sr} / \mathrm{Ca}$ and $\mathrm{Ba} / \mathrm{Ca}$ ratios-diet or diagenesis? Naturwissenschaften. 2002;89:115-9.

22. Hedges RE. Bone diagenesis: an overview of processes. Archaeometry. 2002;44:319-28.

23. Zapata J, Pérez-Sirvent C, Martínez-Sánchez M, Tovar P. Diagenesis, not biogenesis: two late Roman skeletal examples. Sci Tot Environ. 2006;369:357-68.

24. Burton J. Bone chemistry and trace element analysis. In: Katzenberg MASSR, editor. Biological anthropology of the human skeleton. 2nd ed. New York: Wiley; 2008. p. 443-60. 
25. King CL, Tayles N, Gordon KC. Re-examining the chemical evaluation of diagenesis in human bone apatite. J Archaeol Sci. 2001;38:2222-30.

26. Maurer A, Barrulas P, Person A, Mirão J, Barrocas Dias C, Boudouma O, Segalen L. Testing LA-ICP-MS analysis of archaeological bones with different diagenetic histories for paleodiet prospect. Palaeogeogr Palaeoclimatol Palaeoecol. 2019;534:109287.

27. Harkness JS, Darrah TH. From the crust to the cortical: the geochemistry of trace elements in human bone. Geochim Cosmochim Acta. 2019;249:76-94

28. Mays S. Bone strontium: calcium ratios and duration of breastfeeding in a Mediaeval skeletal population. J Archaeol Sci. 2003;30:731-41.

29. Scharlotta I, Goriunova OI, Weber A. Micro-sampling of human bones for mobility studies: diagenetic impacts and potentials for elemental and isotopic research. J Archaeol Sci. 2013;40:4509-27.

30. Skytte L, Rasmussen KL. Sampling strategy and analysis of trace element concentrations by Inductively coupled plasma mass spectrometry on medieval human bones - the concept of chemical life history. Rapid Commun Mass Spectrom. 2013;27:1591-9.

31. Lösch S, Moghaddam N, Grossschmidt K, Risser DU, Kanz F. Stable Isotope and Trace Element Studies on Gladiators and Contemporary Romans from Ephesus (Turkey, 2nd and 3rd Ct. AD) —implications for differences in diet. PLoS ONE. 2014; 9:e110489.

32. Rasmussen KL, Skytte L, D'Imporzano P, Thomsen PO, Søvsø M, Boldsen $J \mathrm{~L}$. On the distribution of trace element concentrations in multiple bone elements in 10 Danish medieval and post-medieval individuals. Am J Phys Anthropol. 2017;162:90-102.

33. Voutchkova DD, Schullehner J, Knudsen NN, Jørg ensen LF, Ersbøll AK, Kristiansen SM, Hansen B. Exposure to Selected Geogenic Trace Elements (I, Li, and Sr) from Drinking Water in Denmark. Geosci. 2015;5;45-66.

34. Tchounwou PB, Ayensu WK, Ninashvili N, Sutton D. Review: environmental exposure to mercury and its toxicopathologic implications for public health. Environ Toxicol. 2003;18:149-75. https://doi.org/10.1002/ tox.10116.

35. Matta G, Gjyli L. Mercury, lead and arsenic impact on environment and human health. J Chem Pharma Sci. 2016;9:718-25.

36. ATSDR. Toxicological Profile for Mercury Atlanta, GA, Agency for toxic substances and disease registry, U.S. Department of Health and Human Services, Public Health Service, 1999

37. Hunt M, Consuegra S. Neolithic and Chalcolithic-VI to III millenia BCuse of cinnabar (HgS) in the Iberian Peninsula: analytical identification and lead isotope data for an early mineral exploitation of the Almadén (Ciudad Real, Spain) mining district. Cuadernos del Museo Geominero. 2011;13:3-13.

38. Keynes M. The personality of Isaac Newton. Notes Records R Soc Lond 1995:49:1-56

39. Fornaciari G, Marinozzi S, Gazzaniga V, Giuffra V, Picchi MS, Giusiani M, Masetti M. The use of mercury against pediculosis in the Renaissance: the case of Ferdinand II of Aragon, King of Naples, 1467-96. Medic Hist. 2011;55:109-15

40. Alexandrovskaya E, Panova T. History of the soil, cultural layer, and people in medieval Moscow. Revista Mexicana de Ciencias Geológicas. 2003;20:289-94

41. Alexandrovskaya E, Alexandrovskiy A. Radiocarbon data and anthropochemistry of ancient Moscow. Geochronometria. 2005;24:87-95.

42. Charlier P. Qui a tué la Dame de Beauté? Étude scientifique des restes d'Agnès Sorel (1422-1450). Histoire des Sciences Médicales. 2006:40:255-63.

43. Rasmussen KL, Boldsen JL, Kristensen HK, Skytte L, Hansen KL, Mølholm L, Grootes PM, Nadeau M-L, Eriksen KMF. Mercury levels in Danish Medieval human bones. J Archaeol Sci. 2008;35:2295-306.

44. Rasmussen KL, Skytte L, Pilekær C, Lauritsen A, Boldsen JL, Leth PM, Thomsen PO. The distribution of mercury and other trace elements in the bones of two human individuals from medieval Denmark - the chemical life history hypothesis. Herit Sci. 2013;1:10.

45. Rasmussen KL, Skytte L, Ramseyer N, Boldsen JL. Mercury in soil surrounding medieval human skeleton. Herit Sci. 2013;1:16.

46. Rasmussen KL, Skytte L, Jensen AJ, Boldsen JL. Comparison of mercury and lead levels in the bones of rural and urban populations in Southern Denmark and Northern Germany during the Middle Ages. J Archaeol Sci Rep. 2015:3:358-70.
47. Ávila A, Mansilla J, Bosch P, Pijoan C. Cinnabar in Mesoamerica: poisoning or mortuary ritual? J Archaeol Sci. 2014;49:48-56.

48. Bocca B, Forte G, Giuffra V, Serra RM, Asara Y, Farace C, Milanese M, Tognotti E, Montella A, Bandiera P, Madeddu R. Metals in bones of the middle-aged inhabitants of Sardinia island (Italy) to assess nutrition and environmental exposure. Environ Sci Pollut Res. 2018;25:8404-14.

49. Cervini-Silva J, Palacios E, Muñoz MDL, Angel PD, Montoya JA, Ramos E, López F, Pacheco AR. Cinnabar-preserved bone structures from primary osteogenesis and fungal signatures in ancient human remains. Geomicrobiol J. 2013;30:566-77.

50. Emslie SD, Brasso R, Patterson WP, Valera CA, McKenzie A, Silva AM, Gleason JD, Blum JD. Chronic mercury exposure in Late Neolithic/Chalcolithic populations in Portugal from the cultural use of cinnabar. Scientific Reports 5. 2015;205:14679. https://doi.org/10.1038/srep14679.

51. Emslie SD, Alderman A, McKenzie A, Brasso R, Taylor AR, Moreno MM, Cambra-Moo O, Martín AG, Silva AM, Valera A, Sanjuán LG, Vila EV. Mercury in archaeological human bone: biogenic or diagenetic? J Archaeol Sci. 2019:108:104969.

52. López-Costas O, Kylander M, Mattielli N, Álvarez-Fernández N, PérezRodríguez M, Mighall T, Bindler R, Cortizas A. Human bones tell the story of atmospheric mercury and lead exposure at the edge of Roman World. Sci Tot Environ. 2020;710:136319.

53. Ochoa-Lugo M, Cervini-Silva J, Muñoz ML, Palacios E, Pérez-Ramirez G, Ramos-Cruz E, Montoya A, Romano-Pacheco A. The effect of depositional conditions on mineral transformation, chemical composition, and preservation of organic material in archaeological bone remains. J Archaeol Sci Rep. 2017:15:213-8.

54. Panova TD, Dmitriev AY, Borzakov SB, Hramco C. Analysis of arsenic and mercury content in human remains of the 16th and 17th centuries from Moscow Kremlin necropolises by neutron activation analysis at the IREN facility and the IBR-2 reactor FLNP JINR. Phys Particles Nuclei Lett. 2018;15:127-34

55. Walser JW, Kristjánsdóttir S, Gowland R, Desnica N. Volcanoes, medicine, and monasticism: investigating mercury exposure in medieval Iceland. Int J Osteoarchaeol. 2019:29:48-61.

56. Yamada M-o, Tohno S, Tohno Y, Minami T, Ichii M, Okazaki Y. Accumulation of mercury in excavated bones of two natives in Japan. Sci Tot Environ. 1995:162:253-256.

57. Rasmussen KL, Torino M, Glastrup J, Ramseyer NT, Bjerregaard P. On the embalmment of S. Francesco Caracciolo. Archaeometry. 2012;54:1100-13.

58. Hu H, Shih R, Rothenberg S, Schwartz BS. The epidemiology of lead toxicity in adults: measuring dose and consideration of other methodologic issues. Environ Health Perspec. 2007;115:455-62.

59. Ellis DE, Terra J, Warschkow O, Jiang M, González GB, Okasinski JS, Bedzyk MJ, Rossi AM, Eon J. A theoretical and experimental study of lead substitution in calcium hydroxyapatite. Phys Chem Chem Phys. 2006;8:967.

60. Pemmer B, Roschger A, Wastl A, Hofstaetter J, Wobrauschek P, Simon $\mathrm{R}$, Thaler H, Roschger P, Klaushofer K, Streli C. Spatial distribution of the trace elements zinc, strontium and lead in human bone tissue. Bone. 2013;57:184-93.

61. Järup L. Hazards of heavy metal contamination. Brit Med Bull. 2003;68:167-82.

62. Rabinowitz MB. Toxicokinetics of bone lead. Environ Health Perspec 1991;91:33-7.

63. Specht AJ, Mostafaei F, Lin Y, Xu J, Nie LH. Measurements of strontium levels in human bone in vivo using portable X-ray fluorescence (XRF). Appl Spectros. 2017;71:1962-8.

64. Retief F, Cilliers L. Lead poisoning in ancient Rome. Acta Theologica. 2010;2010(26):147-64.

65. Lanzirotti A, Bianucci R, LeGeros R, Bromage TG, Giuffra V, Ferroglio E, Fornaciari G, Appenzeller O. Assessing heavy metal exposure in Renaissance Europe using synchrotron microbeam techniques. J Archaeol Sci. 2014;52:204-17.

66. Eda M, Kodama Y, Ishimaru E, Yoneda M. Lead concentration in archaeological animal remains from the edo period, Japan: is the lead concentration in archaeological goose bone a reliable indicator of domestic birds? Int J Osteoarchaeol. 2013:24:265-71.

67. Delile H, Blichert-Toft J, Goiran J, Keay S, Albarede F. Lead in ancient Rome's city waters. Proceed Nat Acad Sci. 2014;2014(111):6594-9. 
68. Scott SR, Shafer MM, Smith KE, Overdier JT, Cunliffe B, Stafford TW, Farrell PM. Elevated lead exposure in Roman occupants of Londinium: new evidence from the archaeological record. Archaeometry. 2019;62:109-29.

69. Aufderheide AC, Neiman FD, Wittmers LE, Rapp G. Lead in bone II: skeletal-lead content as an indicator of lifetime lead ingestion and the social correlates in an archaeological population. Am J Phys Anthropol. 1981;1981(55):285-91.

70. Nakashima T, Matsuno K, Matsushita T. Lifestyle-determined gender and hierarchical differences in the lead contamination of bones from a feudal town of the edo period. J Occupa Health. 2007;49:134-9.

71. Nakashima T, Matsuno K, Matsushita M, Matsushita T. Severe lead contamination among children of samurai families in Edo period Japan. J Archaeol Sci. 2011;38:23-8.

72. Wittmers L, Aufderheide A, Pounds J, Jones K, Angel J. Problems in determination of skeletal lead burden in archaeological samples: an example from the First African Baptist Church population. Am J Phys Anthropol. 2008;136:379-86.

73. Müller K, Chadefaux C, Thomas N, Reiche I. Microbial attack of archaeological bones versus high concentrations of heavy metals in the burial environment. A case study of animal bones from a mediaeval copper workshop in Paris. Palaeogeogr Palaeoclimatol Palaeoecol. 2011;310:39-51.

74. Giovas CM, Kamenov GD, Fitzpatrick SM, Krigbaum J. Sr and Pb isotopic investigation of mammal introductions: pre-Columbian zoogeographic records from the Lesser Antilles, West Indies. J Archaeol Sci. 2016;69:39-53.

75. Sauvé S, Hendershot W, Allen HE. Solid-solution partitioning of metals in contaminated soils: dependence on $\mathrm{pH}$, total metal burden, and organic matter. Environ Sci Tech. 2000;34:1125-31.

76. Angelova M, Asenova S, Nedkova V, Koleva-Kolareva R. Copper in the human organism. Trakia J Sci. 2011;9:88-98.

77. Bost M, Houdart S, Oberli M, Kalonji E, Huneau JF, Margaritis I. Dietary copper and human health: current evidence and unresolved issues. J Trace Elem Med Biol. 2016;35:107-15.

78. Collins JF, Klevay LM. Copper. Adv Nutr. 2011;2:520-2.

79. Committee on Copper in Drinking Water. Copper in drinking water. Washington: National Research Council; 2000.

80. Madsen E, Gitlin JD. Copper and iron disorders of the brain. Ann Rev Neurosci. 2007;30:317-37.

81. Uauy R, Olivares M, Gonzalez M. Essentiality of copper in humans. Am J Clin Nutr. 1998;67:952S-9S.

82. Van den Berghe PV, Klomp LWJ. New developments in the regulation of intestinal copper absorption. Nutr Rev. 2009;67:658-72.

83. Klevay KN. Is the Western diet adequate in copper? J Trace Elem Med Biol. 2011;25:204-12.

84. Medeiros DM. Copper, iron, and selenium dietary deficiencies negatively impact skeletal integrity: a review. Exp Biol Med. 2016;241:1316-22.

85. Allmäe R, Limbo-Simovart J, Heapost L, Verš E. The content of chemical elements in archaeological human bones as a source of nutrition research. Papers Anthropol. 2012;21:27-49.

86. Arrhenius B. Trace element analyses of human skulls. Laborativ Arkeologi. 1990;4:15-9.

87. Buikstra JE, Frankenberg S, Lambert JB, Xue L. Multiple elements: multiple expectations. In: Price TD, editor. The chemistry of prehistoric human bone. Cambridge: Cambridge University Press; 1989. p. 155-210.

88. Ezzo JA. Zinc as a paleodietary indicator: an issue of theoretical validity in bone-chemistry analysis. Am Antiquity. 1994;59:606-21.

89. Schutkowski H, Herrmann B, Wiedemann F, Bocherens H, Grupe G. Diet, status and decomposition at Weingarten: trace element and isotope analyses on early mediaeval skeletal material. J Archaeol Sci. 1999;26:675-85.
90. Rasmussen KL, Milner GR, Delbey T, Skytte L, Søvsø M, Callesen F, Boldsen JL. Copper exposure in medieval and post-medieval Denmark and northern Germany: its relationship to residence location and social position, 2020. Herit Sci. 2020;8:18.

91. Reiche I, Favre-Quattropani L, Vignaud C, Bocherens H, Charlet L, Menu M. A multi-analytical study of bone diagenesis: the Neolithic site of Bercy (Paris, France). Measure Sci Tech. 2003;2003(14):1608-19.

92. Rasmussen KL, Degano I, Colombini MP, Kjeldsen F, van der Plicht J. On the investigation of the supposed bread sack of S. Francesco of Assisi. Radiocarbon. 2017:59:1425-33.

93. Torino M. La vita e la morte a Montella (Avellino) tra il 1200 ed il 1400: primi risultati dello studio sui resti umani rinvenuti durante le campagne di scavo nel Convento di S. Francesco a Folloni in Montella. Annali dell'Università Suor Orsola Benincasa. 2012;333-337.

94. Buikstra JE, Ubelaker DH. Standards for Data Collection from Human Skeletal Remains. In: Proceedings of a Seminar at the Field Museum of Natural History. Research Series 1. Fayetteville, Arkansas Archaeological Survey. 1994.

95. Milner GR, Boldsen JL. Humeral and femoral head diameters in recent white American skeletons. J Foren Sci. 2012;57:35-40.

96. Milner GR, Boldsen JL. Transition analysis: a validation study with known-age modern american skeletons. Am J Phys Anthropol. 2012;148:98-110

97. Milner GR, Boldsen JL, Ousley SD, Weise S, Getz SM, Tarp P. Improved Adult Age Estimation Using New Skeletal Traits and Transition Analysis. Poster presentation at 85th Meeting in American Anthropological Association, April 12th-16th 2016, Atlanta.

98. Qin $Y, L i H$, Yang $X$, Huang $H$, Qin Y, Xie Y. Experimental dissolution of lead from bronze vessels and the lead content of human bones from Western Zhou dynasty tombs in Hengshui, Shanxi, China. J Archaeol Sci. 2015;64:22-9.

99. Fornaciari G, Ciranni R, Busoni CA, Gamba S, Benedetti E, Mallegni F, Nelli S, Rollo F. Santa Zita di Lucca: malattie, ambiente e società dallo studio di una mummia naturale del XIII sec. Edizione "All'insegna del Giglio", 2001;1-6.

100. Pike AWG, Richards MP. Diagenetic arsenic uptake in archaeological bone. Can we really identify copper smelters? J Archaeol Sci. 2002;29:607-11.

101. Rasmussen $\mathrm{KL}$, Bjerregaard P, Gommesen PH, Jensen OL. Arsenic in Danish and Swedish Mesolithic and Neolithic human bones_-diet or diagenesis? J Archaeol Sci. 2009;36:2826-34.

102. Rasmussen KL, Milner G, Skytte L, Lynnerup N, Thomsen JL, Boldsen $J$ L. Mapping diagenesis in archaeological human bones. Herit Sci. 2019;7:41.

103. Jensen AJ. Diagenesis in modern, Danish, Burned Pig Bone. EXARC J Digest. 2016;2016:1.

104. Krajcarz MT. Alteration of the metal content in animal bones after 25-year experimental exposure to sediments. Archaeol Anthropol Sci. 2017;2017(11):361-72.

105. Brodziak-Dopierala B, Kwapulinski J, Kusz D, Gajda Z, Sobczyk K. Interactions between concentrations of chemical elements in human femoral heads. Arch Environ Contam Toxicol. 2009;57:203-10.

106. Kuo HW, Kuo SM, Chou CH, Lee TC. Determination of 14 elements in Taiwanese bones. Sci Total Environ. 2000;255:45-54.

\section{Publisher's Note}

Springer Nature remains neutral with regard to jurisdictional claims in published maps and institutional affiliations. 